\title{
A Conserved Hypothetical Gene Is Required but Not Sufficient for Ptr ToxC Production in Pyrenophora tritici-repentis
}

\author{
Gongjun Shi, ${ }^{1}$ Gayan Kariyawasam, ${ }^{1}$ Sanzhen Liu, ${ }^{2}$ Yueqiang Leng, ${ }^{1}$ Shaobin Zhong, ${ }^{1}$ Shaukat Ali, ${ }^{3}$ \\ Paula Moolhuijzen, ${ }^{4}$ Caroline S. Moffat, ${ }^{4}$ Jack B. Rasmussen, ${ }^{1}$ Timothy L. Friesen, ${ }^{1,5}$ Justin D. Faris, ${ }^{5}$ \\ and Zhaohui Liu ${ }^{1, \dagger}$ \\ ${ }^{1}$ Department of Plant Pathology, North Dakota State University, Fargo, ND 58108, U.S.A. \\ ${ }^{2}$ Department of Plant Pathology, Kansas State University, Manhattan, KS 66506, U.S.A. \\ ${ }^{3}$ Department of Agronomy, Horticulture \& Plant Science, South Dakota State University Brookings, SD 57006, U.S.A. \\ ${ }^{4}$ Center for Crop Disease and Management, School of Molecular and Life Sciences, Curtin University, Bentley, Western \\ Australia, Australia \\ ${ }^{5}$ USDA-ARS Cereal Crops Research Unit, Edward T. Schafer Agricultural Research Center, Fargo, ND 58102, U.S.A. \\ Accepted 27 January 2022.
}

The fungus Pyrenophora tritici-repentis causes tan spot, an important foliar disease of wheat worldwide. The fungal pathogen produces three necrotrophic effectors, namely Ptr ToxA, Ptr ToxB, and Ptr ToxC to induce necrosis or chlorosis in wheat. Both Ptr ToxA and Ptr ToxB are proteins, and their encoding genes have been cloned. Ptr ToxC was characterized as a low-molecular weight molecule 20 years ago but the one or more genes controlling its production in $P$. tritici-repentis are unknown. Here, we report the genetic mapping, molecular cloning, and functional analysis of a fungal gene that is required for Ptr ToxC production. The genetic locus controlling the production of Ptr ToxC, termed ToxC, was mapped to a subtelomeric region using segregating biparental populations, genome sequencing, and association analysis. Additional marker analysis further delimited ToxC to a $173-\mathrm{kb}$ region. The predicted genes in the region were examined for presence/absence polymorphism in different races and isolates leading to the identification of a single candidate gene. Functional validation showed that this gene was required but not sufficient for Ptr ToxC production, thus it is designated as ToxC1. ToxC1 encoded a conserved hypothetical protein likely located on the vacuole membrane. The gene was highly expressed during infection, and only one haplotype was identified among 120 isolates sequenced. Our

${ }^{\dagger}$ Corresponding author: Z. Liu; zhh.liu@ndsu.edu

Gongjun Shi and Gayan Kariyawasam contributed equally.

Funding: This project was supported by the United States Department of Agriculture National Institute of Food and Agriculture Agriculture and Food Research Initiative (USDA-NIFA-AFRI) competitive grants program, award number 2016-67014-24806 to Z. Liu. This work was also supported, in part, by USDA NIFA under Hatch project number ND02234 to Z. Liu.

*The $\boldsymbol{e}$-Xtra $\operatorname{logo}$ stands for "electronic extra" and indicates there are supplementary figures and supplementary tables published online.

The author(s) declare no conflict of interest.

(c) (1) () () Copyright $\odot 2022$ The Author(s). This is an open access article distributed under the CC BY-NC-ND 4.0 International license. work suggests that Ptr ToxC is not a protein and is likely produced through a cascade of biosynthetic pathway. The identification of ToxC1 is a major step toward revealing the Ptr ToxC biosynthetic pathway and studying its molecular interactions with host factors.

Keywords: necrotrophic effectors, Pyrenophora tritici-repentis ToxC, tan spot, fungus-plant interactions, mechanisms of pathogenicity

Pyrenophora tritici-repentis is a destructive necrotrophic fungal pathogen that causes tan or yellow spot on wheat. The disease occurs in almost all wheat-growing regions of the world. Generally, yield loss due to tan spot ranges from 2 to $15 \%$, while, under favorable conditions, tan spot can cause yield losses up to 49\% (Ciuffetti et al. 2014; Hosford 1982; Rees et al. 1982; Shabeer and Bockus 1988). Fungal infection induces necrosis or chlorosis on the leaves of susceptible cultivars, which can reduce leaf photosynthesis and, thus, grain yield. Although tan spot can be partially managed by using cultural practices and timely fungicide application, the use of resistant wheat cultivars is the preferred method for disease control.

Understanding pathogen virulence and how virulence factors interact with the host is important for breeding disease-resistant wheat cultivars. $P$. tritici-repentis is known to produce multiple host-selective toxins (HSTs), now called necrotrophic effectors (NEs), as important virulence factors. Three NEs have been identified and characterized, namely Ptr ToxA, Ptr ToxB, and Ptr ToxC. These NEs specifically interact with their corresponding host sensitivity genes, Tsnl for Ptr ToxA, Tsc2 for Ptr ToxB, and Tscl, for Ptr ToxC to cause disease (Ciuffetti et al. 2010; Faris et al. 2013). The Ptr ToxA-Tsn1 interaction induces necrosis, whereas the Ptr ToxB-Tsc2, and Ptr ToxC-Tscl interactions induce chlorosis. Because the NE-sensitivity gene interactions result in susceptibility, the wheat $-P$. tritici-repentis pathosystem has been described as an inverse gene-for-gene model (Ciuffetti et al. 2010; Wolpert et al. 2002). Based on the production of the three NEs, $P$. tritici-repentis isolates have been classified into eight races with races 2,3 , and 5 producing a single NE, races 1,6 , and 7 producing two of the three NEs, 
race 8 producing all three, and race 4 producing none (Lamari and Strelkov 2010). While the race structure can be complex in some regions, race 1 , which produces both Ptr ToxA and Ptr ToxC, is predominant at the global level, particularly in North America (Aboukhaddour et al. 2013; Ali and Francl 2003; Kamel et al. 2019; Lamari et al. 2005).

Both Ptr ToxA and Ptr ToxB are small proteins, and they have been purified and their encoding genes, mode of action, and protein structure have been well-characterized (Ciuffetti et al. 2010). Ptr ToxA is encoded by a single-copy gene designated ToxA (Ciuffetti et al. 1997). The ToxA gene has also been identified in other wheat fungal pathogens including Parastagonospora nodorum (Friesen et al. 2006), Parastagonospora avenaria f. tritici (McDonald et al. 2013), and Bipolaris sorokiniana (Friesen et al. 2018; McDonald et al. 2018, 2019). Ptr ToxA contains pre- and prodomains and the mature protein is $13.2 \mathrm{kDa}$ after cleavage. An RGD (Arg-Gly-Asp) motif located in the C terminus has been shown to be important for Ptr ToxA biological activity and internalization into plant cells (Manning and Ciuffetti 2005; Manning et al. 2008; Meinhardt et al. 2002). The crystal structure of the protein also suggests the RGD motif may be involved in protein-protein interaction (Sarma et al. 2005). Ptr ToxB is encoded by the ToxB gene, which is present in multiple copies in Ptr ToxB-producing isolates, with the extent of chlorosis-inducing activity correlated to ToxB copy numbers (Aboukhaddour et al. 2012; Amaike et al. 2008; Martinez et al. 2004). Figueroa et al. (2015) showed that Ptr ToxB was an apoplastic effector without the need to enter the plant cell, and the three-dimensional structure of Ptr ToxB and its nonfunctional form, Ptr toxb, have been revealed by using nuclear magnetic resonance (Nyarko et al. 2014).

Ptr ToxC is produced by isolates belonging to races $1,3,6$, and 8 as well as an undesignated-race isolate AR CrossB10 (Ali et al. 2010; Kariyawasam et al. 2016; Strelkov and Lamari 2003). Effertz et al. (2002) partially purified Ptr ToxC, using gel filtration, ion exchange, and reverse-phase chromatography, and described Ptr ToxC as a polar, nonionic, low-molecular weight molecule. However, the chemical nature and identity of Ptr ToxC remains unknown. Ptr ToxC interacts with the wheat sensitivity gene $T s c 1$ to induce extensive chlorosis on wheat leaves, and many quantitative trait loci (QTL) mapping studies have revealed that the Ptr ToxC-Tscl interaction, when present, is an important component for the development of disease on both bread and durum wheat (Effertz et al. 2001; Faris et al. 1997; Kariyawasam et al. 2016; Liu et al. 2017; Sun et al. 2010).

Map-based cloning is a common method to identify virulence genes in fungal pathogens, such as Magnaporthe grisea (Talbot et al. 1993), Cochliobolus sativus (B. sorokiniana) (Zhong et al. 2002), and Zymoseptoria tritici (Zhong et al. 2017). The availability of the high-quality reference genome sequences, and gene annotation and effector gene prediction programs have greatly facilitated map-based cloning in identifying virulence factors and genes of plant-pathogenic fungi (Manning et al. 2013; Moolhuijzen et al. 2018; Sperschneider et al. 2018; Yoshida et al. 2009; Zhong et al. 2017). P. tritici-repentis is a homothallic fungus that carries both MAT1-1-1 and MAT1-2-1 mating-type genes in tandem over $4.5 \mathrm{~kb}$, making it self-fertile (Lepoint et al. 2010) and therefore difficult to generate biparental populations using natural fungal isolates. We recently showed that heterothallic strains of $P$. tritici-repentis can be created by deleting one of the mating-type genes, and genetic crosses can be made between such heterothallic strains to develop segregating biparental populations (Ameen et al. 2017). Various genome sequences are available for $P$. tritici-repentis, including reference-quality assemblies for three race 1 isolates (Manning et al. 2013; Moolhuijzen et al. 2018, 2019), a race 5 isolate (Moolhuijzen et al. 2020a), a new race isolate (Kariyawasam et al. 2021), and draft sequences for several isolates of various races (Manning et al. 2013; Moolhuijzen et al. 2018).

To investigate the genetic control system for Ptr ToxC production, we developed two segregating fungal populations by crossing the Ptr ToxC-producing isolate AR CrossB10 to the two Ptr ToxC-nonproducing isolates 86-124 (race 2) and DW5 (race 5), which were designated as AR86 and ARDW, respectively. The AR86 population was used to construct the first genome-wide genetic linkage map in P. tritici-repentis, facilitating the anchoring of genome sequence assembles (Kariyawasam et al. 2021). In this study, we used both populations to map the one or more genes conditioning Ptr ToxC production, followed by the molecular cloning and functional analysis of a fungal gene that is required but not sufficient for Ptr ToxC production.

\section{RESULTS}

\section{Initial genetic mapping of the locus controlling Ptr ToxC production.}

A total of 112 progeny isolates from the AR86 P. triticirepentis population were phenotyped onto the Ptr ToxC differential wheat line 6B365 and two Ptr ToxC-sensitive wheat lines, Prosper and Harry. Like the parental isolates, the progeny isolates produced either chlorosis or no chlorosis on these lines (Fig. 1). Among the progeny, 49 produced chlorosis whereas 63 did not. The segregation of chlorosis induction in this population fit a $1: 1$ ratio $(P=0.19)$ indicating a single locus controlling Ptr ToxC production. The locus was named ToxC.

We performed whole-genome sequencing of 10 chlorosisproducing isolates and 10 isolates that did not produce chlorosis from the AR86 population as well as the two parental

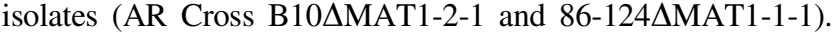
The sequence data obtained for each isolate ranged from 1.32 to $2.06 \mathrm{~Gb}$, which translates to about 33 to $54 \times$ coverage of the $P$. tritici-repentis genome. Sequence alignments against the Pt-1c-BFP reference genome revealed a total of 5,095 single nucleotide polymorphisms (SNPs) between these two parental isolates across the genome. Among them, 26 SNPs were identified to be completely or largely associated with the chlorosis phenotype, suggesting their linkage to ToxC. Of these SNPs, 18 were distributed on supercontig (SC)1.16, four on SC1.38, and two each on SC1.24 and SC1.31 (Table 1). Based on the Pt-1c-BFP optical map, SC1.16 was part of chromosome 2 and $\mathrm{SC} 1.24$ was part of chromosome 8, while the other two (SC1.38 and SC1.31) were not connected to any chromosome (Manning et al. 2013).

Semithermal asymmetric reverse PCR (STARP) and cleaved amplified polymorphic sequence (CAPS) primers were designed from the above SNPs (Supplementary Table S1) and were used to genotype the entire AR86 population. Genetic linkage mapping showed that SNP markers within the first $50 \mathrm{~kb}$ of SC1.16 as well as two markers on SC1.38 cosegregated or were tightly linked to the ToxC locus (Fig. 2). The primers designed from the SNPs on SC1.31 and SC1.24 were not polymorphic, suggesting incorrect calling of those SNPs. A small inversion was observed between the linkage map and the physical contig at the 32- to 46-kb region in the AR86 population (Fig. 2).

\section{ToxC was further mapped to a $173 \mathrm{~kb}$ physical region.}

A whole-genome sequence alignment between the $P$. triticirepentis reference genomes of two race 1 (producing Ptr ToxC) isolates, M4 and Pt-1c-BFP, has been previously published (Moolhuijzen et al. 2018). M4 contig 13 (C13) aligned well with Pt-1c-BFP SC1.16 but in a reverse complementary manner, and it had an extra $159 \mathrm{~kb}$ at the distal end and $66 \mathrm{~kb}$ at the 
proximal end (Fig. 3). We used the extra sequence at the distal end to develop simple sequence repeat (SSR) markers (Supplementary Table S1) and genotyped these markers in the AR86 population. Two SSR markers (M4.C13SSR6 and M4.C13SSR2) at the proximal end of $\mathrm{C} 13$ also cosegregated with the ToxC phenotype (data not shown).

To reduce the size of the candidate region, we genotyped all the above developed markers on the ARDW P. tritici-repentis population. Genetic linkage mapping and phenotyping of two critical recombinants (Supplementary Fig. S1) indicated that ToxC cosegregated with the two SSR markers but was $1.8 \mathrm{cM}$ from Sc1.16.17k (Fig. 3). This delimited the candidate region for ToxC from the $742 \mathrm{~kb}$ position to the end $(915 \mathrm{~kb})$ of contig M4C13, which is about $173 \mathrm{~kb}$ in size (Fig. 3).

\section{Comparative genomics and allelic analysis} of the candidate gene region.

Two reference-quality genome sequences were recently made available, namely V1 (race 1 from Australia, producing Ptr ToxC) and DW5 (from the United States, producing no Ptr ToxC) (Moolhuijzen et al. 2019, 2020a). We aligned the ToxC candidate region of $\mathrm{M} 4 \mathrm{C} 13$ (from 700 to $915 \mathrm{~kb}$ ) to the corresponding regions in these two sequenced isolates. The M4C13 ToxC region aligned well with the first $253 \mathrm{~kb}$ of $\mathrm{V} 1$ chromosome 2 (SAXQ0100002.1) but in a reverse complementary manner. The alignment to DW5 showed good homology for only $50 \mathrm{~kb}$ (700 to $750 \mathrm{~kb}$ on M4 C13 aligned to the 220 to $170 \mathrm{~kb}$ on DW5 Chr.2 Muxc02000002.1), however, no homology was observed for the rest of the sequence. Therefore, sequence alignments did not help to narrow down the candidate region.

A total of 43 genes, designated PtrM4_13120 to PtrM4_13162, were annotated within the $173-\mathrm{kb}$ candidate region of $\mathrm{M} 4 \mathrm{C} 13$ (Moolhuijzen et al. 2018). Using a BLASTn search, we found that four genes, PtrM4_13120, PtrM4_13121, PtrM4_13145, and PtrM4_13157, were each present as single copies in the M4 genome, whereas the other genes had at least two hits with an E value greater than 1.0e-100 (Supplementary Table S2). Primers were designed for all 43 genes (Supplementary Table S1) and were tested on a set of Ptr ToxC-producing and Ptr ToxC-nonproducing isolates for presence/absence polymorphisms (Supplementary Table S3). Only PtrM4_13157 was found to be present in all Ptr ToxC-producing isolates and absent in all Ptr ToxC-nonproducing isolates (Fig. 4; Supplementary Table S3). Another gene, PtrM4_13145, which had $46 \%$ homology to PtrM4_13157 at the amino acid level, was absent in all Ptr ToxC-nonproducing isolates except Biotrigo9-1.

\section{Validation of PtrM4_13157 for Ptr ToxC production} using gene knock-out and complementation analyses.

PtrM4_13157 appeared to be the best candidate gene for ToxC. Therefore, deletion mutants were generated using the split-marker system (Leng and Zhong 2012). A total of 18 transformants were obtained in Pti2 (a race 1 isolate producing Ptr ToxC) and two of them, Pti2 $\Delta 13157-1$ and Pti2 $\Delta 13157-2$, were confirmed by PCR to have the PtrM4_13157 gene successfully deleted (Supplementary Fig. S2). The two knockout mutants had no visible defect in mycelial growth, conidial production, morphology, or germination (data not shown). Following inoculation on the Ptr ToxC-sensitive lines 6B365, Harry, and Prosper, the wild-type Pti2 isolate resulted in extensive chlorosis, whereas the two knockout isolates did not (Fig. 5). However, the two knockout isolates caused a similar amount of disease as Pti2 on Glenlea (the Ptr ToxA differential line), suggesting no change for the production of Ptr ToxA or other factors necessary for virulence (Fig. 5). Furthermore, a bioassay of liquid culture filtrates on Glenlea showed that the disruption of PtrM4_13157 did not affect Ptr ToxA production (Supplementary Fig. S3).

We also performed gene complementation by transforming a 3.67-kb genomic region of PtrM4_13157 to one of the knockout isolates (Pti2 $\Delta 13157-2)$. The two complementation isolates, designated as Pti $2 \Delta 13157+13157-1$ and Pti $2 \Delta 13157+13157-2$, restored the ability to cause chlorosis on the Ptr ToxC sensitive lines (Fig. 5). The result indicated that PtrM4_13157 is required for Ptr ToxC production.

\section{Transformation of PtrM4_13157 \\ into Ptr ToxC-nonproducing isolates.}

PtrM4_13157 was also transformed into Biotrigo9-1, a race 2 isolate that produces Ptr ToxA but not Ptr ToxC. Following inoculation onto the Ptr ToxC differential line 6B365, the wildtype Biotrigo9-1 isolate produced small necrotic lesions, while no chlorosis was observed. However, the two isolates of Biotrigo9-1
86-124DMAT1-1-1

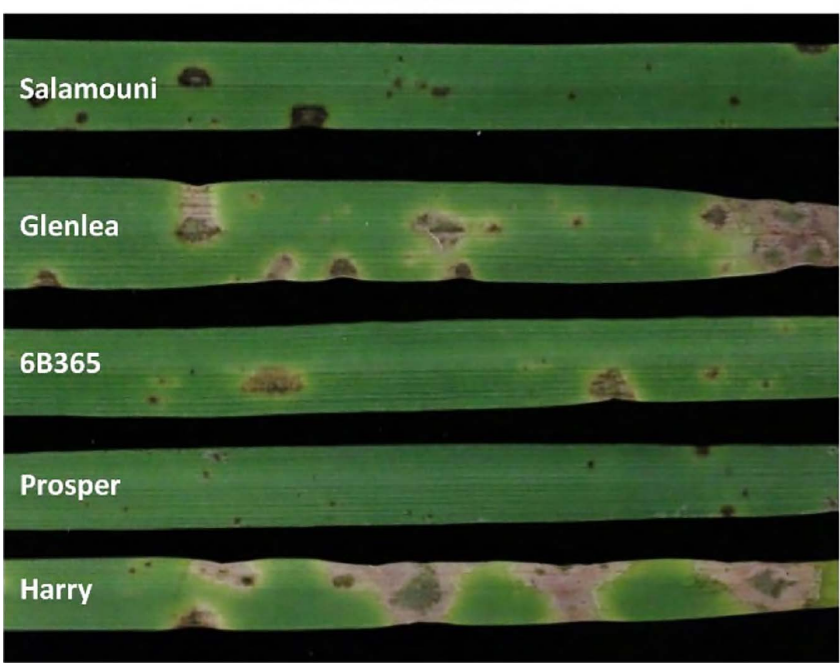

AR CrossB10 1 MAT1-2-1

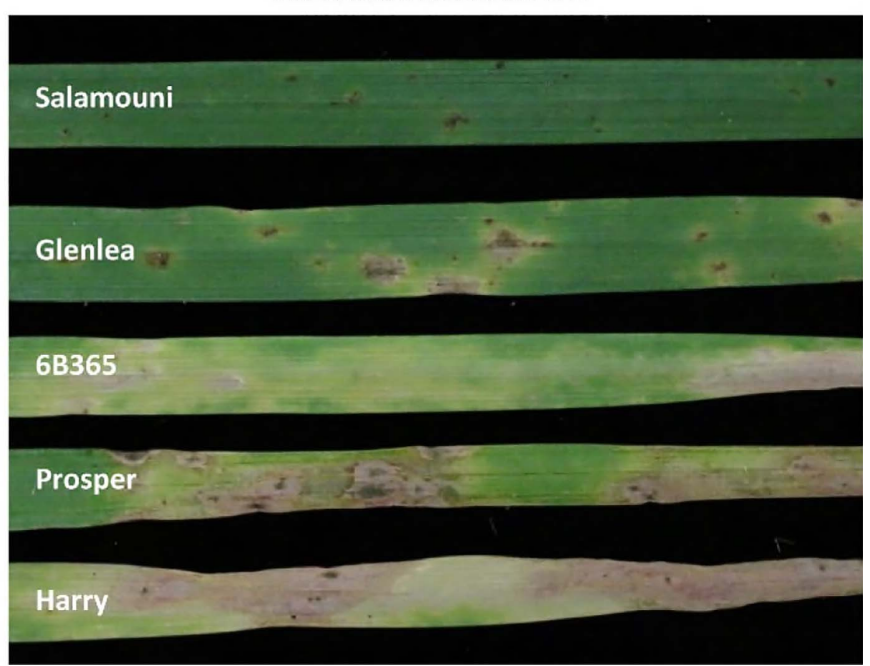

Fig. 1. Reactions of tan spot differentials and other Ptr ToxC-sensitive wheat lines to the two heterothallic Pyrenophora tritici-repentis parent strains

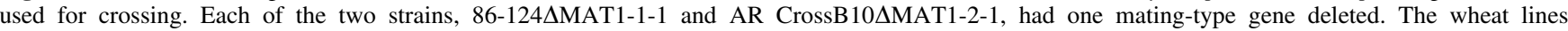
included Salamouni (universal resistant), Glenlea (Ptr ToxA differential), 6B365 (Ptr ToxC differential), Prosper (Ptr ToxC sensitive), and Harry (Ptr ToxC sensitive). AR CrossB10 $\mathrm{MAT1}$-2-1 but not 86-124AMAT1-1-1 caused extensive chlorosis on Ptr ToxC-sensitive lines. 
transformed with PtrM4_13157 (Biotrigo9-1 + 13157-1 and Biotrigo9-1+13157-2) induced extensive chlorosis (Fig. 6A).

The gene was also transformed into DW5, a race 5 isolate that produces Ptr ToxB but not Ptr ToxC. Like the wild-type DW5, the transformant (DW5 + 13157-1-1) did not induce chlorosis on $6 \mathrm{~B} 365$ but still caused chlorotic lesions on the Ptr ToxB differential line 6B662 (Fig. 6B), indicating that another factor necessary for Ptr ToxC production was lacking in DW5. LS13-192 is a race 4 isolate that produces no known NEs and is avirulent on all tan spot differential lines, but it can cause disease on some tetraploid wheat lines (Guo et al. 2020). The two transformants of this isolate with PtrM4_13157 (LS13$192+13157-1$ and LS13-192 + 13157-2) were still avirulent on $6 \mathrm{~B} 365$ without the development of any chlorosis symptoms (Fig. 6C).

\section{PtrM4_13157 controls Ptr ToxC production indicated by QTL mapping in the host.}

Ptr ToxC interacts with the host gene Tscl on the distal end of the wheat chromosome arm 1AS to induce chlorosis and

Table 1. Single nucleotide polymorphisms (SNPs) associated with the chlorosis-inducing phenotype among the parental lines and 20 progeny isolates

\begin{tabular}{|c|c|c|c|c|c|c|c|c|c|c|c|c|}
\hline \multirow[b]{2}{*}{ Supercontig $^{\mathbf{a}}$} & \multirow{2}{*}{$\begin{array}{c}\text { Physical } \\
\text { position }\end{array}$} & \multicolumn{11}{|c|}{ Isolates produced chlorosis ${ }^{b}$} \\
\hline & & ARCrossB10 & AR86.9 & AR86.10 & AR86.26 & AR86.30 & AR86.44 & AR86.68 & AR86.87 & AR86.106 & AR86.128 & AR86.136 \\
\hline \multirow[t]{18}{*}{ SC1.16 } & 9945 & $\mathrm{C}$ & $\mathrm{C}$ & $\mathrm{C}$ & $\mathrm{C}$ & $\mathrm{C}$ & $\mathrm{C}$ & $\mathrm{C}$ & $\mathrm{C}$ & $\mathrm{C}$ & $\mathrm{C}$ & $\mathrm{C}$ \\
\hline & 15685 & $\mathrm{G}$ & $\mathrm{G}$ & $\mathrm{G}$ & $\mathrm{G}$ & $\mathrm{G}$ & $\mathrm{G}$ & $\mathrm{G}$ & $\mathrm{G}$ & $\mathrm{G}$ & $\mathrm{G}$ & $\mathrm{G}$ \\
\hline & 17644 & A & $\mathrm{A}$ & A & A & A & A & A & $\mathrm{A}$ & A & A & A \\
\hline & 18006 & $\mathrm{C}$ & $\mathrm{C}$ & $\mathrm{C}$ & $\mathrm{C}$ & $\mathrm{C}$ & $\mathrm{C}$ & $\mathrm{C}$ & $\mathrm{C}$ & $\mathrm{C}$ & $\mathrm{C}$ & $\mathrm{C}$ \\
\hline & 23270 & A & $\mathrm{A}$ & $\mathrm{A}$ & A & A & $\mathrm{A}$ & A & $\mathrm{A}$ & A & A & A \\
\hline & 33253 & $\mathrm{G}$ & $\mathrm{G}$ & $\mathrm{G}$ & $\mathrm{G}$ & $\mathrm{G}$ & $\mathrm{G}$ & $\mathrm{G}$ & $\mathrm{G}$ & $\mathrm{G}$ & $\mathrm{G}$ & $\mathrm{G}$ \\
\hline & 36697 & $\mathrm{~T}$ & $\mathrm{~T}$ & $\mathrm{~T}$ & $\mathrm{~T}$ & $\mathrm{~T}$ & $\mathrm{~T}$ & $\mathrm{~T}$ & $\mathrm{~T}$ & $\mathrm{~T}$ & $\mathrm{~T}$ & $\mathrm{~T}$ \\
\hline & 37040 & $\mathrm{C}$ & $\mathrm{C}$ & $\mathrm{C}$ & $\mathrm{C}$ & $\mathrm{C}$ & $\mathrm{C}$ & $\mathrm{C}$ & $\mathrm{C}$ & $\mathrm{C}$ & $\mathrm{C}$ & $\mathrm{C}$ \\
\hline & 40905 & $\mathrm{~A}$ & $\mathrm{~A}$ & A & $\mathrm{A}$ & A & A & A & A & A & A & $\mathrm{A}$ \\
\hline & 43815 & G & G & $\mathrm{G}$ & G & $\mathrm{G}$ & $\mathrm{G}$ & $\mathrm{G}$ & G & G & $\mathrm{G}$ & G \\
\hline & 44937 & A & A & A & A & A & A & $\mathrm{A}$ & A & A & A & A \\
\hline & 46099 & A & A & A & A & A & A & A & A & A & $\mathrm{A}$ & $\mathrm{A}$ \\
\hline & 51285 & $\mathrm{G}$ & $\mathrm{G}$ & $\mathrm{G}$ & $\mathrm{G}$ & $\mathrm{G}$ & $\mathrm{G}$ & $\mathrm{G}$ & G & $\mathrm{G}$ & $\mathbf{A}$ & $\mathrm{G}$ \\
\hline & 69802 & A & A & A & $\mathrm{A}$ & A & A & A & A & A & $\mathrm{G}$ & A \\
\hline & 74136 & $\mathrm{G}$ & $\mathrm{G}$ & $\mathrm{G}$ & $\mathrm{G}$ & $\mathrm{G}$ & $\mathrm{G}$ & $\mathrm{G}$ & $\mathrm{G}$ & $\mathrm{G}$ & $\mathbf{A}$ & $\mathrm{G}$ \\
\hline & 78406 & $\mathrm{C}$ & $\mathrm{C}$ & $\mathrm{C}$ & $\mathrm{C}$ & $\mathrm{C}$ & $\mathrm{C}$ & $\mathrm{C}$ & $\mathrm{C}$ & $\mathrm{C}$ & $\mathbf{A}$ & $\mathrm{C}$ \\
\hline & 78429 & $\mathrm{C}$ & $\mathrm{C}$ & $\mathrm{C}$ & $\mathrm{C}$ & $\mathrm{C}$ & $\mathrm{C}$ & $\mathrm{C}$ & $\mathrm{C}$ & $\mathrm{C}$ & $\mathbf{G}$ & $\mathrm{C}$ \\
\hline & 116643 & $\mathrm{C}$ & $\mathrm{C}$ & $\mathrm{C}$ & $\mathrm{C}$ & $\mathrm{C}$ & $\mathrm{C}$ & $\mathrm{C}$ & $\mathrm{C}$ & $\mathrm{C}$ & $\mathbf{A}$ & $\mathrm{C}$ \\
\hline \multirow[t]{2}{*}{ SC1.24 } & 158988 & A & A & A & A & A & A & A & A & A & A & A \\
\hline & 159042 & $\mathrm{~T}$ & $\mathrm{~T}$ & $\mathrm{~T}$ & $\mathrm{~T}$ & $\mathrm{~T}$ & $\mathrm{~T}$ & $\mathrm{~T}$ & $\mathrm{~T}$ & $\mathrm{~T}$ & $\mathrm{~T}$ & $\mathrm{~T}$ \\
\hline \multirow[t]{2}{*}{$\mathrm{SC} 1.31$} & 43707 & $\mathrm{~T}$ & $\mathrm{~T}$ & $\mathrm{~T}$ & $\mathrm{~T}$ & $\mathrm{~T}$ & $\mathrm{~T}$ & $\mathrm{~T}$ & $\mathrm{~T}$ & $\mathrm{~T}$ & $\mathrm{~T}$ & $\mathrm{~T}$ \\
\hline & 43747 & A & A & A & A & A & A & A & A & $\mathbf{C}$ & A & A \\
\hline \multirow[t]{4}{*}{ SC1.38 } & 17670 & $\mathrm{~T}$ & $\mathrm{~T}$ & $\mathrm{~T}$ & $\mathrm{~T}$ & $\mathrm{~T}$ & $\mathrm{~T}$ & $\mathrm{C}$ & $\mathrm{T}$ & $\mathrm{T}$ & $\mathrm{T}$ & $\mathrm{T}$ \\
\hline & 18503 & $\mathrm{C}$ & $\mathrm{C}$ & $\mathrm{C}$ & $\mathrm{C}$ & $\mathrm{C}$ & $\mathrm{C}$ & $\mathrm{C}$ & $\mathrm{C}$ & $\mathrm{C}$ & $\mathrm{C}$ & $\mathrm{C}$ \\
\hline & 18523 & $\mathrm{C}$ & $\mathrm{C}$ & $\mathrm{C}$ & $\mathrm{C}$ & $\mathrm{C}$ & $\mathrm{C}$ & $\mathrm{C}$ & $\mathrm{C}$ & $\mathrm{C}$ & $\mathrm{C}$ & $\mathrm{C}$ \\
\hline & 20648 & A & A & A & A & A & A & A & A & A & A & A \\
\hline
\end{tabular}

Isolates produced no chlorosis

86-124 AR86.12 AR86.29 AR86.35 AR86.48 AR86.63 AR86.82 AR86.91 AR86.101 AR86.109 AR86.12

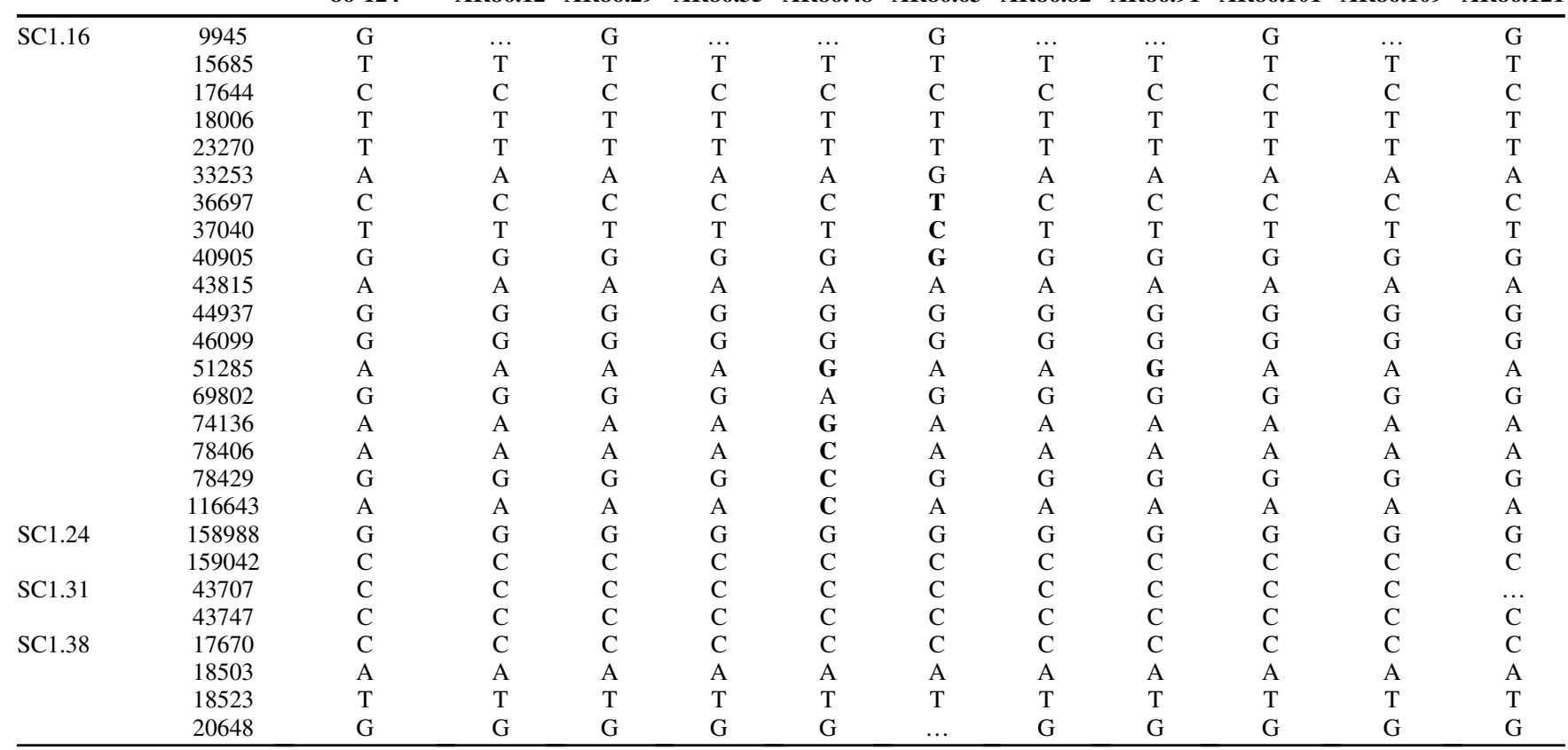

${ }^{\text {a }}$ The reference genome of Pt-1c-BFP (Manning et al. 2013) was used in SNP identifications.

${ }^{\mathrm{b}}$ SNPs that have recombinants between phenotype and genotype were highlighted in bold font and dots represent missing data. 
promote disease. This is why a major QTL associated with disease can be detected at the distal end of 1AS (the Tscl locus) when a Ptr ToxC-producing isolate is used to evaluate a wheat population segregating for Tscl (Faris et al. 1997; Kariyawasam et al. 2016, 2018; Liu et al. 2017). Thus, we evaluated the PtrM4_13157 knockout (Pti2 113157-2) and a gain-of-function transformant (Biotrigo9-1+13157-1) along with their wild-type isolates (Pti2 and Biotrigo9-1) in the PenLou wheat population, which segregates for Tscl (Kariyawasam et al. 2016). A significant QTL with a logarithm of the odds (LOD) score of 5.21 and a $R^{2}$ value of 0.07 was detected on $1 \mathrm{AS}$ at the Tscl locus for the wild-type Pti2 but not for Pti2 $\Delta 13157-2$ (Fig. 7A). This demonstrated that the knockout of PtrM4_13157 did not produce Ptr ToxC, thus eliminating its disease interaction with Tscl in this population. For the PtrM4_13157 gene transformant, a significant QTL was identified at the same position for the Biotrigo9$1+13157-1$ isolate but not for wild-type Biotrigo9-1 (Fig. 7B). The QTL had a slightly higher LOD value of 9.3, indicating that transformation of PtrM4_13157 into Biotrigo9-1 allowed the strain to produce Ptr ToxC, which interacts with $T s c l$ to cause disease. A major QTL on 3BL was detected for all four isolates (Supplementary Fig. S4), suggesting the disruption or introduction of PtrM4_13157 caused no change for the production of the virulence factor, which interacts with this $3 \mathrm{BL}$ host gene to cause disease.
PtrM4 13157 full-length complementary DNA (cDNA), expression profile, and protein characterization.

To characterize the full-length cDNA of PtrM4_13157, 5' and $3^{\prime}$ rapid amplification of cDNA ends (RACE) was conducted. The results showed that transcription of this gene starts $325 \mathrm{bp}$ upstream of the start codon and stops at $119 \mathrm{bp}$ downstream of the stop codon, with two introns located within the $5^{\prime}$ untranslated region (UTR) (Supplementary Fig. S5). The coding region was $675 \mathrm{bp}$ long without introns. The result matched the annotation of this gene in the reference genome Pt-1c-BFP, designated as PTRT_12046 (accession number XM_001942394.1). Quantitative PCR revealed that the expression of PtrM4_13157 was the highest at $72 \mathrm{~h}$ after inoculation (hai), approximately 9.36 times higher than that at 3 hai (Supplementary Fig. S6). The expression of PtrM4_13157 was also detected in mycelium and was up-regulated more than 30 -fold at 72 hai (Supplementary Fig. S6).

PtrM4_13157 encoded a 224-aa protein with no signal peptide or known motifs. BLASTp searches of the National Center of Biotechnology Information (NCBI) database detected no conserved domains but resulted in a total of 97 hits with percent identity ranging from 36.17 to $53.67 \%$ (Supplementary Fig. S7). Most of the hits were annotated as conserved hypothetical proteins and the top two were COCVIDRAFT_20059 (XP_014551713.1) from Bipolaris victoriae FI3 (score $=201$ bits, identity $=57 \%$ ) and

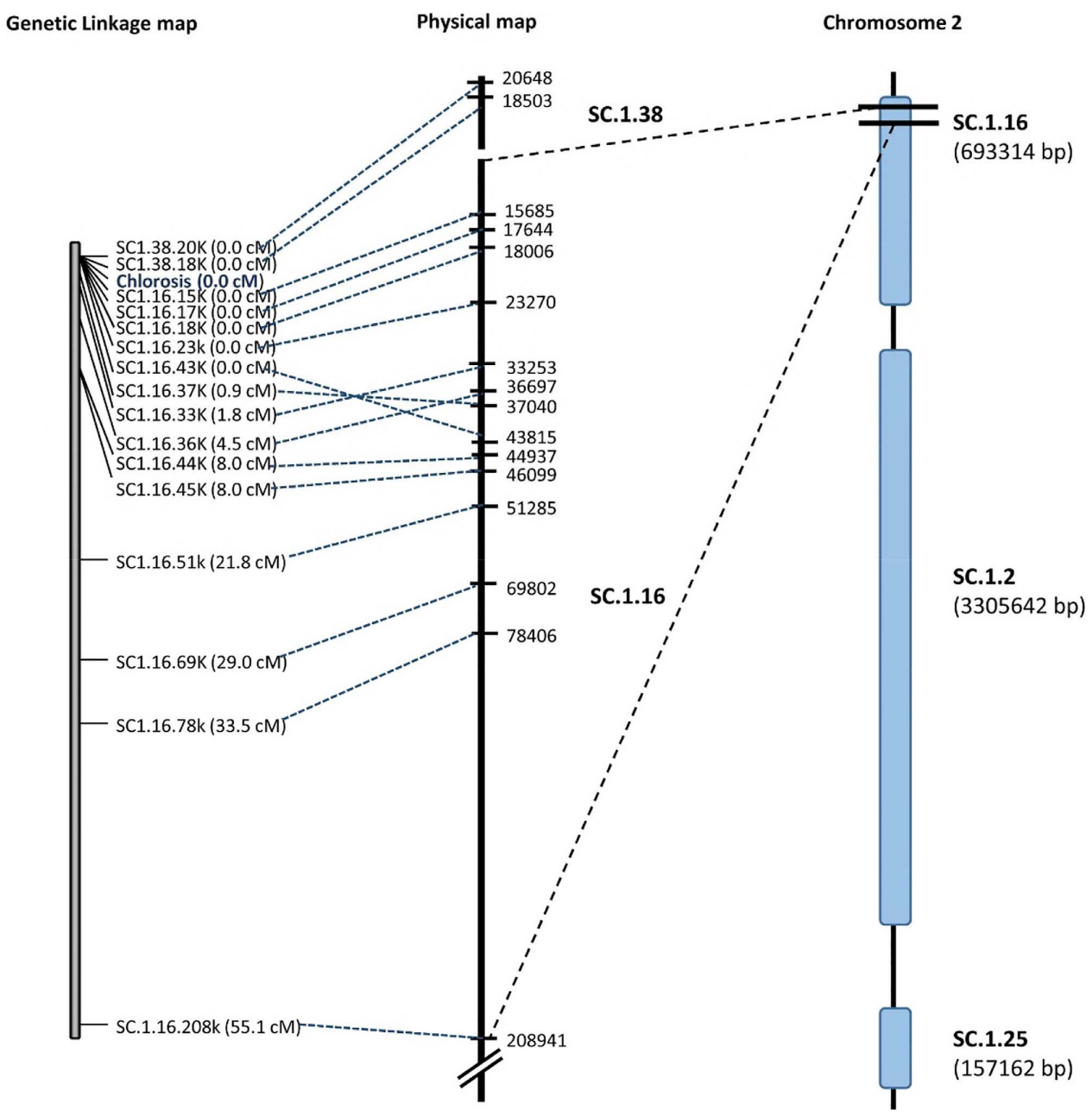

Fig. 2. Genetic linkage map of the Pyrenophora tritici-repentis genomic region conditioning Ptr ToxC production (chlorosis development in sensitive wheat lines) in the AR86 population. A linkage map in centimorgans is on the left, its corresponding physical map regions in base pairs of Pt-1C-BFP is in the middle, and chromosome 2 with the supercontigs is on the right. The markers on the linkage map were designed based on their physical positions on corresponding supercontigs. The chlorosis (chlorosis development in sensitive lines) locus is indicated in blue as the ToxC locus. The total length of each supercontig on chromosome 2 is shown within brackets. 
COCCADRAFT_112548 (Xp_007718585.1) from Bipolaris zeicola $26-\mathrm{R}-13$ ( score $=197$, identity $=53 \%)$. Interestingly, one of these hits was annotated as premRNA-splicing factor slu7 (RFU73058.1) of Trichoderma arundinaceum (score = 163 , identity $=46 \%$ ). Surprisingly, there was no hit from the related wheat and barley fungal pathogens Parastagonospora nodorum, $P$. teres and $B$. sorokiniana. Cellular location prediction using DeepLoc-1.0 suggested that it is a membrane protein, likely on the lysosome or vacuole (Supplementary Fig. S8).

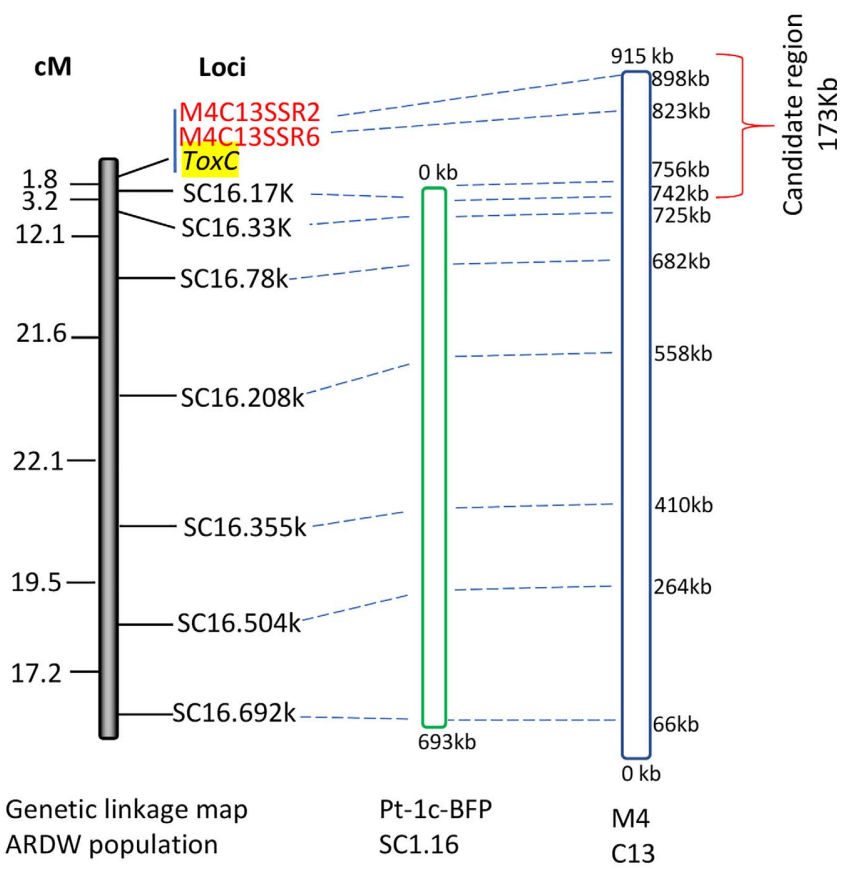

Fig. 3. Genetic mapping of ToxC in the ARDW Pyrenophora triticirepentis population and identification of the candidate region. The linkage map constructed with markers on supercontig 1.16 is on the left. Two markers in red were developed by using the extra sequence from M4 contig 13. The marker genetic distances are indicated to the left of the linkage map. The entire supercontig1.16 (693 kb long) of Pt-1c-BFP is in the middle and contig 13 of M4 is on the right. Dashed lines indicate the physical positions of each marker in the two contigs from the reference genomes Pt-1C-BFP and M4

\section{PtrM4_13157 diversity analysis.}

BLASTn searches showed that PtrM4_13157 was present as a single-copy gene with an identical sequence in all the sequenced genomes of Ptr ToxC-producing isolates, namely Pt1C-BFP, M4, AR CrossB10, V1, Ptr239, Ptr134, Ptr1137, and Ptr1453, but was completely absent in all the sequenced genomes of the Ptr ToxC-nonproducing isolates, DW5, 86-124, and SD24. We further investigated the presence and diversity of PtrM4_13157 in a more diverse fungal collection that consisted of $594 P$. tritici-repentis isolates (Supplementary Table S4). Most of the isolates were collected from the United States (409) and Brazil (144), with the remaining from Australia, Canada, Czech Republic, Pakistan, Uruguay, and Poland. These isolates were collected from 1973 to 2020. PCR results showed that PtrM4_13157 was present in $453(76 \%)$ of these isolates. Using the Ptr ToxC differential line 6B365, we phenotyped 123 isolates that carried PtrM4_13157 and all produced chlorosis, while 25 isolates that do not carry this gene did not produce chlorosis (Supplementary Table S4). We sequenced the PtrM4_13157 coding region from a total of 120 isolates of different geographic origins and collection years, and the results showed only one haplotype without any sequence polymorphism (Supplementary Table S4). All the sequences have been submitted to the NCBI GenBank database with accession numbers from OL800416 to OL800536.

\section{DISCUSSION}

Ptr ToxC is produced by the majority of $P$. tritici-repentis isolates worldwide and has been consistently shown to be important for tan spot disease in both hexaploid and tetraploid wheat (Faris et al. 2013; Liu et al. 2020). However, the first and only study for Ptr ToxC identification and characterization was published 20 years ago (Effertz et al. 2002). In that study, the difficulty in Ptr ToxC purification and instability of the compound was also noted. Until now, the chemical nature and how it is produced by the fungus have remained unknown. In this work, we identified a fungal gene (PtrM4_13157), using a genetic approach along with genome sequencing, and demonstrated that PtrM4_13157 is required for Ptr ToxC production, using gene knockouts, gain-of-function transformation, and host QTL analysis. This is a significant step toward revealing the chemical nature of Ptr ToxC and understanding the molecular mechanism of Ptr ToxC production in the pathogen as well as its interaction

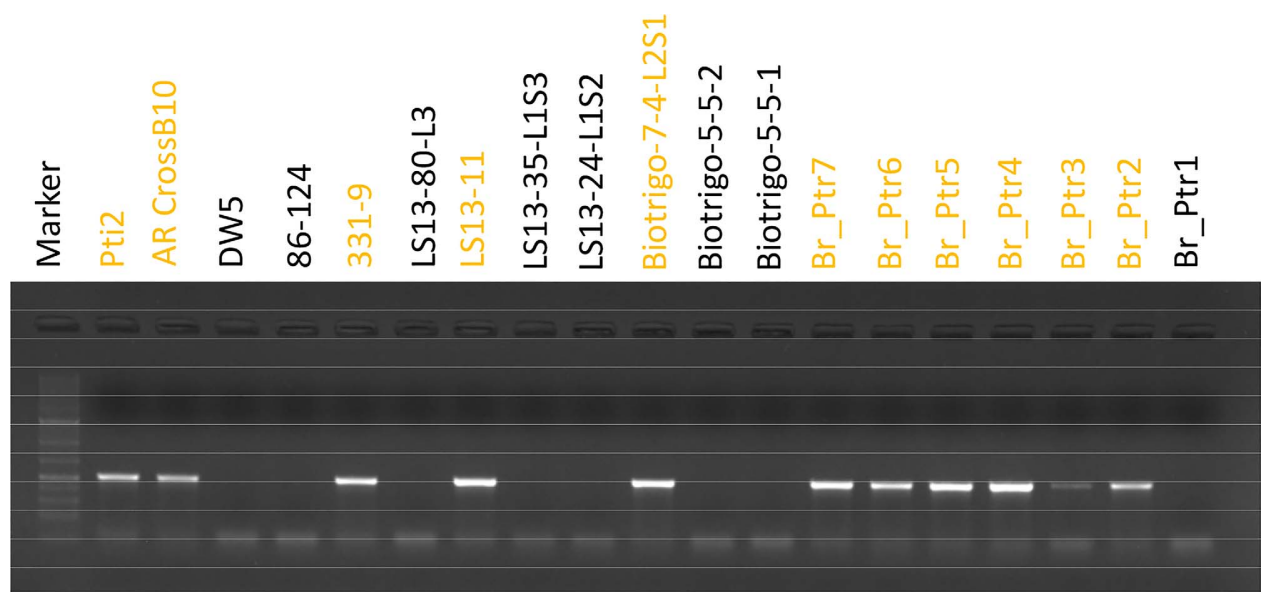

Fig. 4. PCR amplification of PtrM4_13157 in a set of Pyrenophora tritici-repentis isolates. The primer pair M4.13157F and M4.13157R (Supplementary Table S1) was used to amplify the partial coding region of PtrM4_13157. All these isolates are known to cause chlorosis or not on Ptr ToxC-sensitive lines by fungal inoculations (Supplementary Table S3). Isolates causing chlorosis are shown in orange. 
with the host that results in chlorosis, pathogen colonization, and disease development.

The initial characterization by Effertz et al. (2002) suggested that Ptr ToxC was a nonionic, polar, low-molecular weight molecule. We showed that transformation of PtrM4_13157 into two Ptr ToxC-nonproduing isolates, DW5 and LS13-192, did not result in Ptr ToxC production or the induction of extensive chlorosis on the ToxC differential line 6B365. This suggested that Ptr ToxC is not a protein directly encoded by PtrM4_13157 but, rather, something else, likely a secondary metabolite produced through a biosynthetic pathway involving PtrM4_13157. Many fungal-produced NEs (HSTs) are secondary metabolites that require nonribosomal peptide synthetase (NPS) or polyketide synthase (PKS) or both for their production, e.g., T-toxin (Inderbitzin et al. 2010) and HC-toxin (Wight et al. 2013). Victorin, a pentapeptide molecule produced by $B$. victoriae was previously thought to be synthesized through a NPS, but a recent study revealed that it is a member of a ribosomally synthesized and posttranslationally modified peptide (RiPP) (Kessler et al. 2020). We noticed that the ToxC candidate region has no NPS or PKS genes predicted in the reference genomes of M4 and V1, which both produce Ptr ToxC (Moolhuijzen et al. 2018, 2019, 2020b). It is also interesting to note that the most significant hit of PtrM4_13157 in the NCBI protein database was COCVIDRAFT_20059 (XP_014551713.1) from the B. victoriae isolate FI3. However, at this point, there is no direct evidence that Ptr ToxC is a RiPP nor synthesized by a NPS or PKS. Much work is needed to address this question.

Based on our results, PtrM4_13157 is required but not sufficient to produce Ptr ToxC, suggesting the requirement of one or more other genes. We designate PtrM4_13157 as ToxC1 because it is the first gene shown to be required for Ptr ToxC production. The next logical question is, what other gene or genes are required for Ptr ToxC production? Since the Ptr ToxC chlorosis phenotype mapped to a single locus in both fungal biparental populations, we believe that one or more additional genes involved in the Ptr ToxC pathway are likely also present in this same 173-kb region (Table 1; Figs. 2 and 3). Three genes, PtrM4_13133, PtrM4_13134, PtrM4_13145, in this region were present in Biotrigo $9-1$ but absent in all other Ptr ToxC-nonproducing isolates (Supplementary Table S3). Additionally, we showed that the transformation of Biotrigo9-1 with ToxCl led to Ptr ToxC production, but the same did not occur for isolates DW5 and LS13-192 (Fig. 6). Together, this suggested that these three genes are strong candidates for additional ToxC genes involved in Ptr ToxC production. In
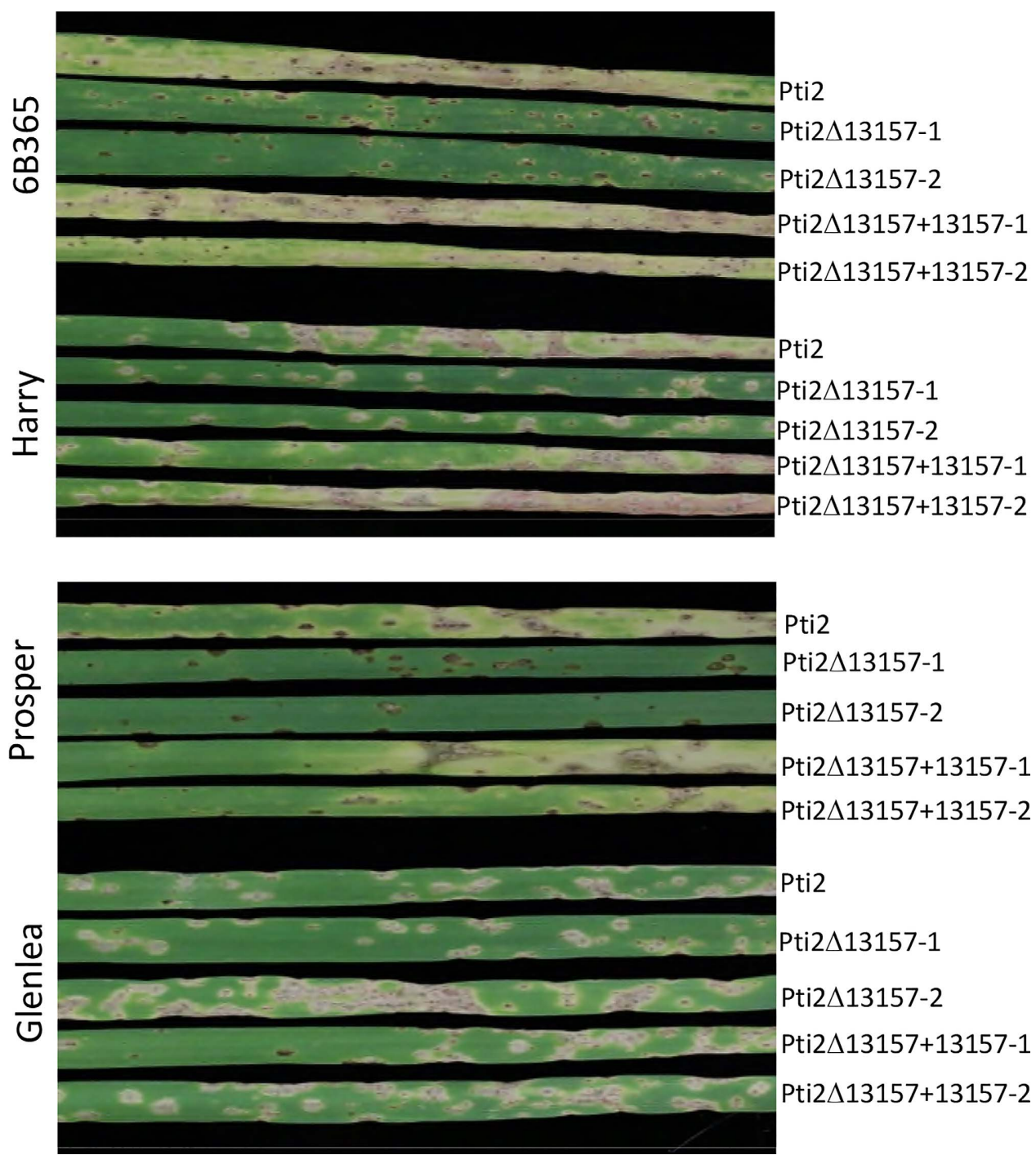

Fig. 5. Phenotyping of Pti2 wild type, PtrM4_13157 knockout, and complementation strains on tan spot different lines. $6 \mathrm{~B} 365$ is the Ptr ToxC differential line. Harry and Prosper are Ptr ToxC-sensitive lines. Glenlea is a Ptr ToxA differential line. Two PtrM4_13157 knockout strains (Pti2 $13157-1$ and Pti2 $\Delta 13157-2)$ and two complementation strains based on Pti2 $\Delta 13157-2$ were included for validation. 
particular, PtrM4_13145, which is a homolog of PtrM4_13157, serves as a top candidate. We are working to validate the function of these genes by knocking them out in Ptr ToxCproducing isolates (e.g., Pti2, M4) and transforming them together with ToxCl into Ptr ToxC-nonproducing isolates (e.g., DW5, 86-124). A high-quality genome sequence assembly covering the ToxC region for Biotrigo9-1 and 86-124 would be highly desirable for identifying the additional genes involved in Ptr ToxC production. It was determined that the ToxC locus controls Ptr ToxC production, but we cannot rule out the possibility of other genomic loci that did not segregate in these two populations being involved in the production of Ptr ToxC. The ToxCl knockout strains are powerful tools that can be used to investigate and identify the possible downstream genes involved in Ptr ToxC production through a genome-wide transcriptional analysis.

The ToxC locus was mapped to the subtelomeric region of chromosome 2 in $P$. tritici-repentis. Very recently, the ToxB genes have also been located, by genome sequence analysis, to the subtelomeric regions of two chromosomes (Moolhuijzen et al. 2020a). In contrast, ToxA was located in the middle of chromosome 6 (Kariyawasam et al. 2021; Manning et al. 2013;

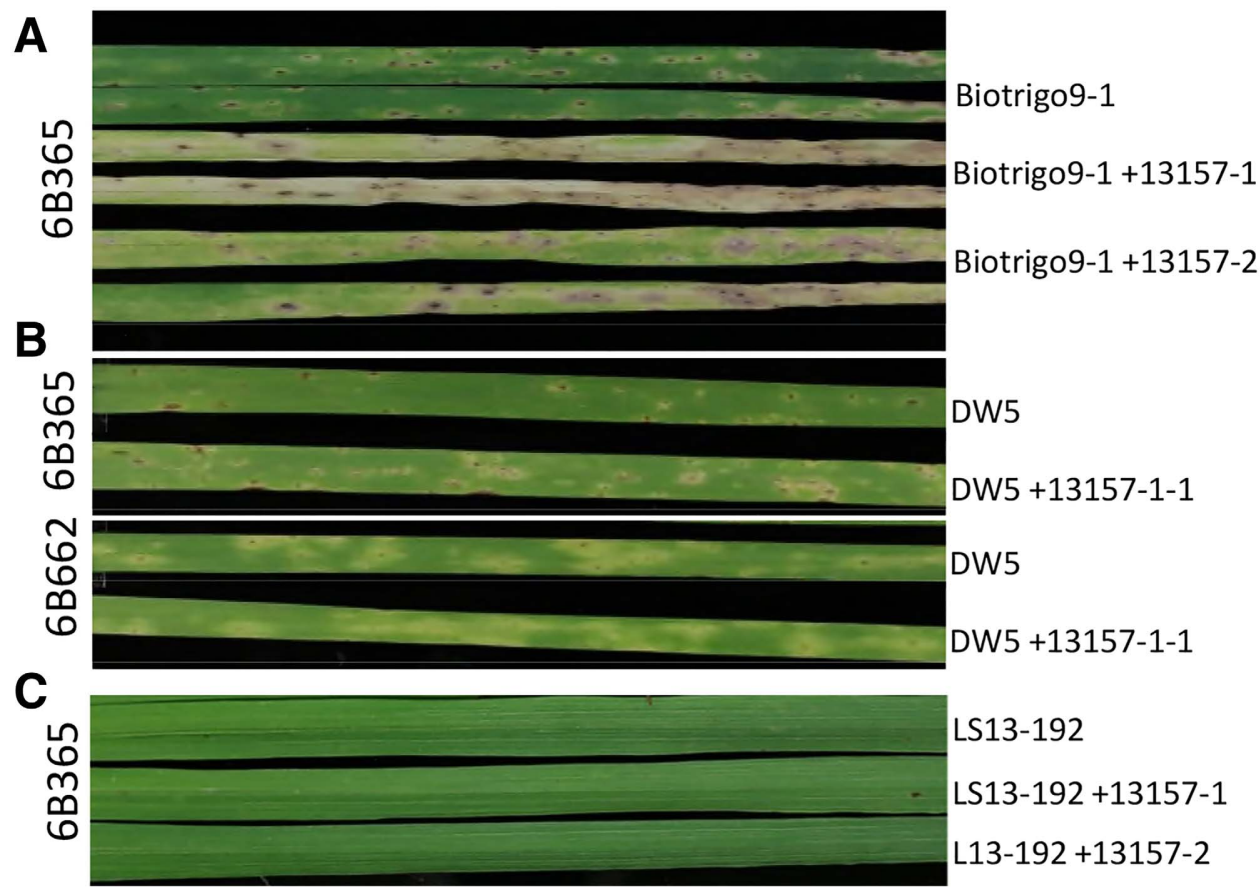

Fig. 6. Phenotyping of PtrM4_13157 transformants in different Pyrenophora tritici-repentis isolates on differential wheat lines. A, Inoculations of Biotrigo9-1 (a race 2 isolate) wild type and its PtrM4_13157 transformant (+13157-1/-2) on the Ptr ToxC differential line 6B365. B, Inoculation of DW5 and its PtrM4_13157 transformant (+13157-1-1) on the Ptr ToxC differential line 6B365 and Ptr ToxB differential line 6B662. C, Inoculation of LS13-192 and its PtrM4_13157 transformant (+13157-1/-2) on the Ptr ToxC differential line 6B365.

A

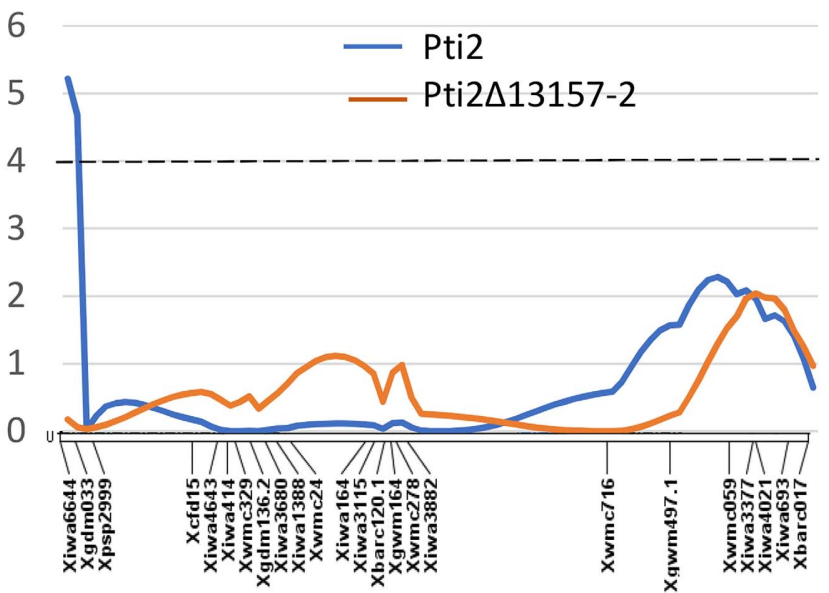

B

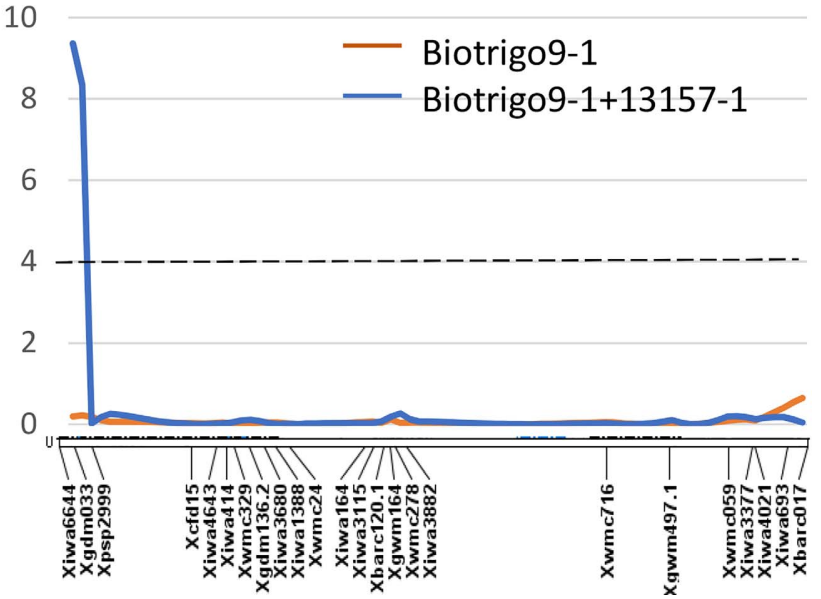

Fig. 7. Composite interval mapping of wheat chromosome $1 \mathrm{~A}$ for quantitative trait loci (QTL) significantly associated with tan spot disease in the PenLou population. A, Pti2 wild type (blue) and Pti2 $\Delta$ 13157-2 (orange); B, Bitrigo9-1 (orange) and Biotrigo9-1+ 13157-1 transformant (blue). The chromosome is drawn below the QTL line with marker loci shown beneath the linkage groups and the positions of marker loci on the scale of centimorgans shown on the top of the linkage groups. The $y$ axis indicates the logarithm of the odds (LOD) scale. A dashed line represents the LOD of the significance threshold of 4.0 for QTL detection. 
Moolhuijzen et al. 2018). This suggests that these $P$. triticirepentis effector genes likely have undergone different evolutionary histories. $P$. tritici-repentis was previously considered a weak pathogen, but sometime prior to the 1940 s, it became a highly virulent wheat pathogen, likely by acquiring ToxA from Parastagonospora nodorum (Friesen et al. 2006). ToxA has also been found in $B$. sorokiana, and genome sequence comparison among Parastagonospora nodorum, $P$. tritici-repentis, and $B$. sorokinana isolates suggested horizontal gene transfer of ToxA together with the surrounding region, likely spanning 140 to 250 $\mathrm{kb}$, which contains transposons (McDonald et al. 2018, 2019). Subtelomeric regions are composed of large amounts of repetitive DNA and have a high level of plasticity in the fungal genomes (Croll et al. 2013). Many fungal effector genes have been reported to reside in these dynamic regions (Chuma et al. 2011; Wyatt et al. 2020). It is not surprising that ToxB and ToxCl are found in the subtelomeric regions. ToxB has ten copies, with nine being clustered on chromosome 11 and one on chromosome 5 (Moolhuijzen et al. 2020a). ToxB may have evolved from multiple breakage and fusion events between telomeric regions that led to the formation of multiple copies and two loci in race 5 or deletion in races 1 and 2 (Moolhuijzen et al. 2020a). As for ToxC, genome alignment indicated that the whole ToxC region $(170 \mathrm{~kb})$ was absent in DW5. It seems that isolate 86-124 does not carry the ToxC region as the genetic linkage mapping showed no recombination within the region in the AR86 population (Fig. 2). The absence of the ToxC region in DW5 and 86-124 may also result from a breakage and fusion event, eliminating the region in Ptr ToxC-nonproducing isolates.

We sequenced the ToxCl coding region from a set of 120 geographically diverse $P$. tritici-repentis isolates and detected no sequence diversity. This is similar to the findings for both ToxA and ToxB in $P$. tritici-repentis. From a collection of global $P$. tritici-repentis isolates, there was only one haplotype identified for ToxA, which contrasted with the 11 haplotypes identified from a global collection of Parastagonospora nodorum isolates (Friesen et al. 2006). Although ToxB also has a nonfunctional form (toxb) in P. tritici-repentis races as well as homologs in Pyrenophora bromi and other fungal pathogens, the sequence for the functional ToxB from all copies and isolates is identical (Martinez et al. 2001, 2004; Moolhuijzen et al. 2020a; Strelkov et al. 2006). Besides the NE genes, genome sequencing of different $P$. tritici-repentis isolates revealed a very low number of SNPs across the whole genome (approximately one SNP every $5 \mathrm{~kb}$ ) (Kariyawasam et al. 2021; Manning et al. 2013; this study) suggesting a relatively short evolutionary history of $P$. tritici-repentis as a pathogen. The fungus was not considered a major pathogen until the late 1970 s, when reduced tillage practices were widely adopted worldwide (Faris et al. 2013). However, some studies did reveal a high level of genetic diversity in various $P$. tritici-repentis populations using molecular markers or mating-type genes (Aboukhaddour et al. 2009, 2011; Friesen et al. 2005; Leisova et al. 2008; Lepoint et al. 2010; Moreno et al. 2008). More studies are needed to examine population diversity in $P$. tritici-repentis and to understand the evolution of its virulence factors.

The expression of ToxCl was found to be highest at 3 days postinoculation (dpi), which is correlated to the time of chlorosis symptom development. Under greenhouse conditions, we usually observed chlorosis symptoms at 4 dpi and progressing to a full extent at $7 \mathrm{dpi}$ (data not shown). This is slightly later than ToxA and ToxB, which showed peak expression between 24 and 48 hai (Amaike et al. 2008; Hernandez et al. 2014; Mironenko et al. 2020). ToxA expression was shown to be regulated by PtrPf2, a GAL-4-like putative zinc finger transcription factor; however, it was not clear if Ptr ToxC production was or was not regulated by PtrPf2 (Rybak et al. 2017). Like
ToxA and ToxB, the expression of ToxC1 was highly detectable in mycelial tissue (Supplementary Fig. S6). Unlike Ptr ToxA and Ptr ToxB, Ptr ToxC production in Pti2 liquid culture was not easily detectable using a plant bioassay on the differential line 6B365 (data not shown), possibly due to insufficient quantity of Ptr ToxC produced in culture to cause chlorosis (Effertz et al. 2002).

In conclusion, we identified the first gene in $P$. tritici-repentis, ToxC1 (PtrM4_13157), that is required for the production of Ptr ToxC, an important NE in the wheat tan spot disease system. We further demonstrated that ToxC1 alone is not sufficient to produce Ptr ToxC, suggesting the requirement of one or more additional genes in the biosynthesis of Ptr ToxC. The ToxCl gene structure, expression, and diversity were also characterized. This work marks significant progress in revealing the molecular basis of Ptr ToxC production and its role in causing disease. Better understanding of Ptr ToxC production will help develop tools for breeding wheat cultivars specifically against $\mathrm{Ptr}$ ToxC-producing isolates of $P$. tritici-repentis.

\section{MATERIALS AND METHODS}

\section{Fungal isolates, populations, and collections.}

Two biparental fungal populations, designated AR86 and ARDW, were used in this study for the genetic linkage mapping of ToxC. The development of the AR86 population was described by Kariyawasam et al. (2021). Briefly, the Ptr ToxC-producing isolate $\mathrm{AR}$ CrossB10 and the Ptr ToxC-nonproducing isolates 86-124 and DW5 first underwent deletion of one of their matingtype genes so as to convert them into heterothallic strains. This was followed by crossing the two strains on dried corn leaf fragments and picking up segregating ascospores produced (Friesen et al. 2003). The same procedure was used to develop the ARDW population, which was derived from the cross between mating-type gene modified strains AR Cross B10 $\Delta$ MAT1-1-1 and DW5 $\triangle$ MAT1-2-1 (race 5, ToxC-nonproducing isolate).

All the progeny isolates from the AR86 population were phenotyped on the Ptr ToxC differential wheat line 6B365 to monitor chlorosis development as the indicator for the production of Ptr ToxC. After phenotyping, $10 \mathrm{Ptr}$ ToxC-producing and 10 Ptr ToxC-nonproducing progeny isolates were selected for whole-genome sequencing and association mapping of the ToxC gene (Table 1). All the progeny isolates of the ARDW population were genotyped with markers in the ToxC region to refine the candidate region leading to the identification of two critical recombinants, ARDW.15 and ARDW.143. A set of 25 isolates including eight ToxC-producing and 17 nonproducing isolates including ARDW.15 and ARDW.143 were used in allelic analysis for the candidate genes within the ToxC region (Supplementary Table S3). Pti2 (race 1 producing Ptr ToxC [Liu et al. 2015]), Biotrigo 9-1 (race 2 producing no Ptr ToxC, collected from Brazil, this study), DW5 (race 5 producing no Ptr ToxC [Liu et al. 2015]) and LS13-192 (race 4 producing no known NEs [Guo et al. 2020]) were used for PtrM4_13157 gene knockout or complementary and transformation experiments. A total of 594 isolates from different geographical regions, including North America (412 isolates), South America (150 isolates), Europe (nine isolates), Asia (one isolate), and Australia (22 isolates), were used in investigating the prevalence of the ToxCl gene, and a subset of these isolates containing ToxCl were used for its sequence diversity analysis (Supplementary Table S4).

\section{Fungal culturing and genomic DNA extraction.}

All fungal isolates were stored as dried plugs in a $-80^{\circ} \mathrm{C}$ freezer. To activate the fungus, the plugs were cultured on V8-potato dextrose agar plates in darkness at room temperature 
for 5 days. Mycelium tissue was collected for each isolate by gently scratching the surface of the culture and, then, grinding the tissue for genomic DNA extraction, following the procedure described by Shjerve et al. (2014).

The culturing method to induce conidia production was the same as previously described (Lamari and Bernier 1989). When the culture was ready, conidia were collected with a sterilized inoculation loop after adding about $30 \mathrm{ml}$ of sterilized distilled water and were then inoculated into 500-ml flasks containing $60 \mathrm{ml}$ of Fries' medium (Liu et al. 2004). Young mycelium produced in the liquid culture was collected for fungal protoplasting and transformation (Ameen et al. 2017). The liquid culture was also used for the production of NEs as described by Friesen and Faris (2012).

\section{Disease phenotyping.}

Fungal progenies were phenotyped by inoculating onto Ptr ToxC-sensitive wheat lines including 6B365 (Ptr ToxC differential line), Prosper (NDSU spring wheat cultivar [Mergoum et al. 2013]), Harry (a Nebraskan winter wheat line [Kariyawasam et al. 2018]), and Jerry (hard red winter wheat cultivar [Liu et al. 2015]). In addition, the differential wheat lines Glenlea (Ptr ToxA differential line), Salamouni (universal resistant line), and 6B662 (Ptr ToxB differential line) were also included for each inoculation. The wheat lines were arranged in half of an RL98 rack with the outside border planted with Jerry.

The fungal inoculations were performed when the plants reached the two- to three-leaf stage. Fungal cultures and inoculation preparation were performed according to the standard procedure described by Lamari and Bernier (1989). Fungal spores (conidia) were harvested from the plates and were adjusted to approximately 2,000 spores per milliliter for inoculation. Disease reactions were scored at $7 \mathrm{dpi}$, based on the presence or absence of chlorosis. The production of chlorosis on the sensitive wheat lines was considered to denote the isolate as possessing the gene conditioning Ptr ToxC production. The experiment was repeated at least three times to obtain consistent data for each progeny.

\section{Genome sequencing and associated SNP identification.}

The genome sequencing of parental lines and 20 progeny isolates from the AR86 population was contracted to Novogene Corporation, where the DNA extraction, library preparation and genome sequencing were completed. The sequencing was performed on the Illumina Hi-Seq 2500 platform with a target of obtaining at least $1 \mathrm{Gbp}$ sequence for each isolate (approximately $25 \times$ coverage). Raw sequences for each isolate were cleaned using Trimmomatic v.0.36 (Bolger et al.2014). Cleaned sequenced reads were aligned to the reference sequence Pt-1cBFP (Manning et al. 2013), using the Burrows-Wheeler Aligner with the 'bwa mem' function (Li and Durbin 2010), and a SAM file was developed for each isolate. Each SAM file was converted to a BAM file using SAMtools with the 'view' command (Li et al. 2009). The resulting BAM files were converted to sorted BAM files with the 'sort' command, and those sorted BAM files were indexed using the 'index' command in SAMtools. Reference sequence was indexed using the 'faidx' command of SAMtools. These sorted indexed BAM files and indexed reference sequence was used for downstream SNP calling.

SNP calling was performed with the use of the Unified Genotype program in the Genome Analysis Tool Kit (GATK) (McKenna et al. 2010). SNPs with a minimum confidence of 30.0 were called using the '-glm' function and output '.vcf' file was used to select a subset of polymorphic variants using the GATK SelectVariants program (S. Liu et al. 2012). Associated SNPs are those for which all ToxC-producing isolates consistently had one genotype and all ToxC-nonproducing isolates consistently had the other genotype.

\section{Marker development and linkage mapping.}

These associated SNPs were used to develop CAPS markers (Konieczny and Ausubel 1993) or STARP markers (Long et al. 2017) and were then genotyped in the entire population. To develop CAPS markers, sequences spanning 150 bp upstream and downstream from SNPs were extracted and forward and reverse primers were designed using Primer3 v. 0.4.0 (Untergasser et al. 2012). Sequences that spanned the SNP were screened for restriction sites using NEBcutter v.2.0. When CAPS markers were impossible to develop, STARP strategy was then used to develop markers for the rest of the SNPs as explained by Long et al. (2017).

The genetic linkage mapping was performed with all the marker data using Mapdisto (Lorieux 2012). Linkage groups were formed using the 'find group' function with a LOD value of 5.0 and $r$ max value of 0.35 . The correct order of the markers was obtained using the 'order sequence', 'check inversions', 'ripple order', and 'drop locus' functions. The obtained SNP markers were aligned to the reference Pt-1c-BFP genome to identify the candidate region responsible for Ptr ToxC production.

\section{PtrM4_13157 gene knockout and transformation.}

The split-marker system was used to delete the candidate gene PtrM4_13157 (renamed as PtrM4_073760 in the new version of M4 genome sequence NQIK00000000.2, Supplementary Table S3). Briefly, two pairs of specific primers were designed based on the 5' and $3^{\prime}$ flanking sequence of the target PtrM4 13157 gene and were used for amplification of $5^{\prime}$ and $3^{\prime}$ gene-specific fragments for overlapping PCR (Supplementary Table S1). The overlapping fragments of the hygromycinresistance gene cassette were amplified from pDAN (Z. Liu et al. 2012) using the $\mathrm{M} 13 \mathrm{~F} / \mathrm{HY} 2$ and $\mathrm{M} 13 \mathrm{R} / \mathrm{YG}$ primers, respectively. To generate the $5^{\prime}$ construct, $\mathrm{PCR}$ products amplified by M4.13157KOF1/F2 and M13F/HY2 were used as templates and primers M4.13157KOF1 and HY2 were used in the fusion PCR. To generate the $3^{\prime}$ construct, PCR products amplified by M4.13157KOF3/F4 and M13R/YG were used as templates and primers M4.13157KOF4 and YG were used in the fusion PCR. Then, the $5^{\prime}$ and $3^{\prime}$ constructs were mixed, were purified by ethanol precipitation, and were used for transformation.

To generate the complementary strains, a $3.67-\mathrm{kb}$ sequence of the PtrM4_13157 genomic region, including the coding region as well as the upstream promoter, were amplified from isolate Pti2, using primer pair Apa_TCF1 and SmaI_TCR1 containing the indicated restriction site. The PCR product was cloned into vector pBG418 (Leng and Zhong 2012) after double digestion with ApaI and SmaI. The resulting plasmid, designated pBG418-PtrM4_13157, containing the PtrM4_13157 gene and a geneticin-resistance gene, was linearized with NotI and was used to transform Ptr ToxC-nonproducing isolates Biotrigo9-1, DW5, LS13-192, and Pti2 $\Delta 13157-2$ mutant.

The fungal protoplasting and polyethylene glycol-mediated transformation followed the procedure described by Ameen et al. (2017). The regenerated clones were screened with PCR primers M4.13157KOF and M4.13157KOR (Supplementary Table S1), which amplify the partial coding region of PtrM4_13157 that was replaced by the hygromycin-resistance gene cassette.

\section{QTL mapping in the wheat population.}

The PenLou wheat mapping population consisted of 188 recombinant inbred lines (RILs) derived from a cross between soft spring wheat cultivar Louise and cultivar Penawawa. The population segregates for the $T s c 1$ gene, which confers a major QTL for disease following inoculation with Ptr ToxC-producing isolates (Kariyawasam et al. 2016). Two parental lines and all RILs were planted along with tan spot differential lines in RL98 
racks for disease evaluation, as described by Kariyawasam et al. (2016). When the plants reached the three-leaf stage, approximately 14 days after planting, the population was evaluated individually for reaction to Pti2 and Pti2 $\Delta 13157-2$, Biotrigo9-1, and Biotrigo9-1 + 13157-1, as described above. At least three biological replications were carried out for disease evaluation, following a randomized complete block design. Disease means from three replications were used in QTL analysis.

The genetic linkage map of PenLou population reported by Kariyawasam et al. (2016) was used for QTL analysis, which contained 596 markers covering all 21 wheat chromosomes. QTL analysis was performed using QGene 4.0 (Joehanes and Nelson 2008). Composite interval mapping was performed, as described by Faris et al. (2014), to identify genomic regions significantly associated with tan spot disease. A permutation test consisting of 1,000 permutations yielded a LOD threshold of 4.0 at an experiment-wise significance level of 0.05 .

\section{Bioinformatic tools and analyses.}

All the available $P$. tritici-repentis genome sequences in NCBI GenBank were downloaded and stored in a local drive, including the following isolates (with NCBI accession numbers): 86-124 (NRDI01000000), AR CrossB10 (JADZLV010000000), DW5 (MUXC02000000), M4 (NQIK01000000), Pt-1C-BFP (AAXI01000000), and V1 (SAXQ01000000). BioEdit (Hall 1999) was used for local blast search and sequence extraction manipulations. The NCBI online BLASTn tool was used for two or more large sequence alignments. Signal peptide identification was performed using web-based SignalP 5.0 (Almagro Armenteros et al. 2019). The proteins were analyzed for the presence of known motifs on the Prosite website. The predication of protein cellular location was done using web-based software DeepLoc-1.0 (Almagro Armenteros et al. 2017).

PtrM4_13157 5' and $3^{\prime}$ race, sequencing, and alignments.

Total RNA was isolated from leaf tissue of the ToxC differential line 6B365 after inoculation with Pti2 and was used for cDNA synthesis, as previously described (Z. Liu et al. 2012). The 5' and $3^{\prime}$ RACE was performed, using the SMART RACE cDNA amplification kit (Clontech), to determine the 5'and $3^{\prime}$ UTRs and introns with gene-specific primers (Supplementary Table S1). PCR products of RACE reactions were purified and were sequenced at the Eurofin genomic facility. The sequences from $5^{\prime}$ and $3^{\prime}$ RACE fragments were used to manually assemble the full-length cDNA.

The presence and absence of ToxCl was screened through PCR with primer pair M4.13157F and M4.13157R in a total of $594 P$. tritici-repentis isolates that originated from five geographical regions: Australia (22 isolates), Europe (nine isolates), Asia (one isolate), North America (412 isolates), and South America (150 isolates) (Supplementary Table S4). PCR reactions were performed using the primer pair M4.13157fullF and M4.13157fullR for further diversity analysis (Supplementary Table S1). The PCR product was purified using PCR Cleanup kit ExoSAP-IT (Applied Biosystems) and were sent directly to the Eurofin genomic facility for sequencing. Sequences were aligned with PtrM4_13157 reference sequence using web-based software Multalin.

\section{Quantitative PCR (qPCR) analysis of ToxC1 transcription during infection.}

The Ptr ToxC differential line 6B365 was used for the ToxC1 in-planta transcription study. Plants at the two-week stage were inoculated with isolate Pti2. The secondary leaf tissue was collected from the inoculated leaves at 1, 3, 6, 12, and $24 \mathrm{~h}$ and 2, 3,4 , and 5 dpi. RNA was extracted from leaf samples using the RNeasy plant mini kit (Qiagen) and was treated with RNase- free DNase I (Qiagen). RNA quantification, cDNA synthesis, and gene transcription analysis were conducted as described (Faris et al. 2010). Gene-specific primers M4.13157F and M4.13157R (Supplementary Table S1) were used for ToxC1 qPCR analysis and P. tritici-repentis Actl was used as an internal control. qPCR was performed on a CFX Opus 96 real-time PCR system (Bio-Rad). Each experiment was conducted with three biological and technical replicates. The 20- $\mu$ l PCRs contained 1× SYBR PCR MasterMix (Applied Biosystems), 0.25 $\mu \mathrm{M}$ of each primer, and $5 \mu \mathrm{l}$ of 10 -fold diluted cDNA. The thermocycler procedure was as follows: $10 \mathrm{~min}$ of preincubation at $95^{\circ} \mathrm{C}$, followed by 40 cycles for $15 \mathrm{~s}$ at $95^{\circ} \mathrm{C}$ and for $1 \mathrm{~min}$ at $60^{\circ} \mathrm{C}$. Transcript levels were expressed as the ratio between the initial numbers of molecules in the target and the internal control using the $2^{-\Delta \Delta C T}$ method.

\section{AUTHOR-RECOMMENDED INTERNET RESOURCES}

Multalin website: http://multalin.toulouse.inra.fr/multalin

Prosite website: https://prosite.expasy.org

\section{LITERATURE CITED}

Aboukhaddour, R., Cloutier, S., Ballance, G. M., and Lamari, L. 2009. Genome characterization of Pyrenophora tritici-repentis isolates reveals high plasticity and independent chromosomal location of ToxA and ToxB. Mol. Plant Pathol. 10:201-212.

Aboukhaddour, R., Cloutier, S., Lamari, L., and Strelkov, S. E. 2011. Simple sequence repeats and diversity of globally distributed populations of Pyrenophora tritici-repentis. Can. J. Plant Pathol. 33:389-399.

Aboukhaddour, R., Kim, Y. M., and Strelkov, S. E. 2012. RNA-mediated gene silencing of ToxB in Pyrenophora tritici-repentis. Mol. Plant Pathol. 13:318-326.

Aboukhaddour, R., Turkington, T. K., and Strelkov, S. E. 2013. Race structure of Pyrenophora triciti-repentis (tan spot of wheat) in Alberta, Canada. Can. J. Plant Pathol. 35:256-268.

Ali, S., and Francl, L. J. 2003. Population race structure of Pyrenophora tritici-repentis prevalent on wheat and noncereal grasses in the Great Plains. Plant Dis. 87:418-422.

Ali, S., Gurung, S., and Adhikari, T. B. 2010. Identification and characterization of novel isolates of Pyrenophora tritici-repentis from Arkansas. Plant Dis. 94:229-235.

Almagro Armenteros, J. J., Sønderby, C. K., Sønderby, S. K., Nielsen, H., and Winther, O. 2017. DeepLoc: Prediction of protein subcellular localization using deep learning. Bioinformatics 33:3387-3395.

Almagro Armenteros, J. J., Tsirigos, K. D., Sønderby, C. K., Petersen, T. N., Winther, O., Brunak, S., von Heijne, G., and Nielsen, H. 2019. SignalP 5.0 improves signal peptide predictions using deep neural networks. Nat. Biotechnol. 37:420-423.

Amaike, S., Ozga, J. A., Basu, U., and Strelkov, S. E. 2008. Quantification of ToxB gene expression and formation of appressoria by isolates of Pyrenophora tritici repentis differing in pathogenicity. Plant Pathol. 57:623-633.

Ameen, G., Kariyawasam, G., Shi, G., Friesen, T. L., Faris, J. D., Ali, S., Rasmussen, J. B., and Liu, Z. 2017. Molecular manipulation of the mating-type system and development of a new approach for characterizing pathogen virulence in Pyrenophora tritici-repentis. Fungal Genet. Biol. 109:16-25.

Bolger, A. M., Lohse, M., and Usadel, B. 2014. Trimmomatic: A flexible trimmer for Illumina sequence data. Bioinformatics 30:2114-2120.

Chuma, I., Hotta, Y., and Tosa, Y. 2011. Instability of subtelomeric regions during meiosisin Magnaporthe oryzae. J. Gen. Plant Pathol. 77:317-325.

Ciuffetti, L. M., Manning, V. A., Pandelova, I., Betts, M. F., and Martinez, J. P. 2010. Host-selective toxins, Ptr ToxA and Ptr ToxB, as necrotrophic effectors in the Pyrenophora tritici-repentis-wheat interaction. New Phytol. 187:911-919.

Ciuffetti, L. M., Manning, V. A., Pandelova, I., Faris, J. D., Friesen, T. L., Strelkov, S. E., Weber, G. L., Goodwin, S. B., Wolpert, T. J., and Figueroa, M. 2014. Pyrenophora tritici-repentis: A Plant Pathogenic Fungus with Global Impact. Pages 1-39 in: Genomics of PlantAssociated Fungi: Monocot Pathogens. Springer. Berlin.

Ciuffetti, L. M., Tuori, R. P., and Gaventa, J. M. 1997. A single gene encodes a selective toxin causal to the development of tan spot of wheat. Plant Cell 9:135-144. 
Croll, D., Zala, M., and McDonald, B. A. 2013. Breakage-fusion-bridge cycles and large insertions contribute to the rapid evolution of accessory chromosomes in a fungal pathogen. PLoS Genet. 9:e1003567.

Effertz, R. J., Anderson, J. A., and Francl, L. J. 2001. Restriction fragment length polymorphism mapping of resistance to two races of Pyrenophora tritici-repentis in adult and seedling wheat. Phytopathology 91:572-578.

Effertz, R. J., Meinhardt, S. W., Anderson, J. A., Jordahl, J. G., and Francl, L. J. 2002. Identification of a chlorosis-inducing toxin from Pyrenophora tritici-repentis and the chromosomal location of an insensitivity locus in wheat. Phytopathology 92:527-533.

Faris, J. D., Anderson, J. A., Francl, L. J., and Jordahl, J. G. 1997. RFLP mapping of resistance to chlorosis induction by Pyrenophora triticirepentis in wheat. Theor. Appl. Genet. 94:98-103.

Faris, J. D., Liu, Z., and Xu, S. S. 2013. Genetics of tan spot resistance in wheat. Theor. Appl. Genet. 126:2197-2217.

Faris, J. D., Zhang, Q., Chao, S., Zhang, Z., and Xu, S. S. 2014. Analysis of agronomic and domestication traits in a durum $\times$ cultivated emmer wheat population using a high-density single nucleotide polymorphismbased linkage map. Theor. Appl. Genet. 127:2333-2348.

Faris, J. D., Zhang, Z., Lu, H., Lu, S., Reddy, L., Cloutier, S., Fellers, J. P., Meinhardt, S. W., Rasmussen, J. B., Xu, S. S., Oliver, R. P., Simons, K. J., and Friesen, T. L. 2010. A unique wheat disease resistance-like gene governs effector-triggered susceptibility to necrotrophic pathogens Proc. Natl. Acad. Sci. U.S.A. 107:13544-13549.

Figueroa, M., Manning, V. A., Pandelova, I., and Ciuffetti, L. M. 2015. Persistence of the host-selective toxin Ptr ToxB in the apoplast. Mol. Plant-Microbe Interact. 28:1082-1090.

Friesen, T. L., Ali, S., Francl, L. J., and Rasmussen, J. B. 2003. Rapid and efficient production of the Pyrenophora tritici-repentis teleomorph. Can. J. Bot. 81:890-895

Friesen, T. L., Ali, S., Klein, K. K., and Rasmussen, J. B. 2005. Population genetic analysis of a global collection of Pyrenophora tritici-repentis, causal agent of tan spot of wheat. Phytopathology 95:1144-1150.

Friesen, T. L., and Faris, J. D. 2012. Characterization of plant-fungal interactions involving necrotrophic effector producing plant pathogens. Pages 191-207 in: Plant Fungal Pathogens: Methods and Protocols. M. D. Bolton, and B. P. H. J. Thomma, eds. Humana Press, New York.

Friesen, T. L., Holmes, D. J., Bowden, R. L., and Faris, J. D. 2018. ToxA is present in the United States Bipolaris sorokiniana population and is a significant virulence factor on wheat harboring Tsn1. Plant Dis. 102:2446-2452.

Friesen, T. L., Stukenbrock, E. H., Liu, Z., Meinhardt, S., Ling, H., Faris, J. D., Rasmussen, J. B., Solomon, P. S., McDonald, B. A., and Oliver, R. P. 2006. Emergence of a new disease as a result of interspecific virulence gene transfer. Nat. Genet. 38:953-956.

Guo, J., Shi, G., Kalil, A., Friskop, A., Elias, E., Xu, S. S., Faris, J. D. and Liu, Z. 2020. Pyrenophora tritici-repentis race 4 isolates cause disease on tetraploid wheat. Phytopathology 110:1781-1790.

Hall, T. A. 1999. BioEdit: A user-friendly biological sequence alignment editor and analysis program for Windows 95/98/NT. Nucleic Acids Symp. Ser. 41:95-98.

Hernandez, J., Manning, V., Iovanna, P., and Ciuffetti, L. M. 2014. Small secreted proteins of Pyrenophora tritici-repentis and their role in wheat infection. Undergraduate research paper. Oregon State University, Corvallis, OR, U.S.A. https://ir.library.oregonstate.edu/concern/defaults/q237ht362.

Hosford, R. M., Jr. 1982. Tan spot-developing knowledge 1902-1981, virulent races and wheat differentials, methodology, rating systems, other leaf diseases, and literature. Pages 1-24 in: Tan Spot of Wheat and Related Diseases Workshop. Agricultural Experimental Station, North Dakota State University, Fargo, ND, U.S.A.

Inderbitzin, P., Asvarak, T., and Turgeon, B. G. 2010. Six new genes required for production of T-toxin, a polyketide determinant of high virulence of Cochliobolus heterostrophus to maize. Mol. PlantMicrobe Interact. 23:458-472.

Joehanes, R., and Nelson, J. C. 2008. QGene 4.0, an extensible Java QTL-analysis platform. Bioinformatics 24:2788-2789.

Kamel, S., Cherif, M., Hafez, M., Despins, T., and Aboukhaddour, R 2019. Pyrenophora tritici-repentis in Tunisia: Race structure and effector genes. Front. Plant Sci. 10:1562.

Kariyawasam, G. K., Carter, A. H., Rasmussen, J. B., Faris, J., Xu, S. S., Mergoum, M., and Liu, Z. 2016. Genetic relationships between racenonspecific and race-specific interactions in the wheat-Pyrenophora tritici-repentis pathosystem. Theor. Appl. Genet. 129:897-908.

Kariyawasam, G. K., Hussain, W., Easterly, A., Guttieri, M., Belamkar, V., Poland, J., Venegas, J., Baenziger, S., Marais, F., Rasmussen, J. B., and Liu, Z. 2018. Identification of quantitative trait loci conferring resistance to tan spot in a biparental population derived from two Nebraska hard red winter wheat cultivars. Mol. Breed. 38:140.
Kariyawasam, G. K., Wyatt, N., Shi, G., Liu, S., Yan, C., Ma, Y., Zhong, S., Rasmussen, J. B., Moolhuijzen, P., Moffat, C. S., Friesen, T. L., and Liu, Z. 2021. A genome-wide genetic linkage map and reference quality genome sequence for a new race in the wheat pathogen Pyrenophora tritici-repentis. Fungal Genet. Biol. 152:103571.

Kessler, S. C., Zhang, X., McDonald, M. C., Gilchrist, C. L. M., Lin, Z. Rightmyer, A., Solomon, P. S., Turgeon, B. G., and Chooi, Y.-H 2020. Victorin, the host-selective cyclic peptide toxin from the oat pathogen Cochliobolus victoriae, is ribosomally encoded. Proc. Natl. Acad. Sci. U.S.A. 117:24243-24250.

Konieczny, A., and Ausubel, F. M. 1993. A procedure for mapping Arabidopsis mutations using co-dominant ecotype-specific PCR-based markers. Plant J. 4:403-410.

Lamari, L., and Bernier, C. C. 1989. Evaluation of wheat lines and cultivars to tan spot [Pyrenophora tritici-repentis] based on lesion type. Can. J. Plant Pathol. 11:49-56.

Lamari, L., and Strelkov, S. E. 2010. The wheat/Pyrenophora triticirepentis interaction: Progress towards an understanding of tan spot disease. Can. J. Plant Pathol. 32:4-10.

Lamari, L., Strelkov, S. E., Yahyaoui, A., Amedov, M., Saidov, M., Djunusova, M., and Koichibayev, M. 2005. Virulence of Pyrenophora tritici-repentis in the countries of the Silk Road. Can. J. Plant Pathol. 27:383-388.

Leisova, L., Hanzalova, A., and Kucera, L. 2008. Genetic diversity of Pyrenophora tritici-repentis isolates as revealed by AFLP analysis. J. Plant Pathol. 90:233-245.

Leng, Y., and Zhong, S. 2012. Sfp-type 4'-phosphopantetheinyl transferase is required for lysine synthesis, tolerance to oxidative stress and virulence in the plant pathogenic fungus Cochliobolus sativus. Mol. Plant Pathol. 13:375-387.

Lepoint, P., Renard, M. E., Legrève, A., Duveiller, E., and Maraite, H. 2010. Genetic diversity of the mating type and toxin production genes in Pyrenophora tritici-repentis. Phytopathology 100:474-483.

Li, H., and Durbin, R. 2010. Fast and accurate long-read alignment with Burrows-Wheeler transform. Bioinformatics 26:589-595.

Li, H., Handsaker, B., Wysoker, A., Fennell, T., Ruan, J., Homer, N., Marth, G., Abecasis, G., Durbin, R., and 1000 Genome Project Data Processing Subgroup. 2009. The sequence alignment/Map format and SAMtools. Bioinformatics 25:2078-2079.

Liu, S., Yeh, C.-T., Tang, H. M., Nettleton, D., and Schnable, P. S. 2012. Gene mapping via bulked segregant RNA-Seq (BSR-Seq). PLoS One 7:e36406.

Liu, Y., Salsman, E., Wang, R., Galagedara, N., Zhang, Q., Fiedler, J. D., Liu, Z., Xu, S., Faris, J. D., and Li, X. 2020. Meta-QTL analysis of tan spot resistance in wheat. Theor. Appl. Genet. 133:2363-2375.

Liu, Z., El-Basyoni, I., Kariyawasam, G., Zhang, G., Fritz, A., Hansen, J., Marais, F., Friskop, A., Chao, S., Akhunov, E., and Baenziger, P. S. 2015. Evaluation and association mapping of resistance to tan spot and Stagonospora nodorum blotch in adopted winter wheat germplasm. Plant Dis. 99:1333-1341.

Liu, Z., Zhang, Z., Faris, J. D., Oliver, R. P., Syme, R., McDonald, M. C., McDonald, B. A., Solomon, P. S., Lu, S., Shelver, W. L., Xu, S., and Friesen, T. L. 2012. The cysteine rich necrotrophic effector SnTox 1 produced by Stagonospora nodorum triggers susceptibility of wheat lines harboring Snn1. PLoS Pathog. 8:e1002467.

Liu, Z., Zurn, J. D., Kariyawasam, G., Faris, J. D., Shi, G., Hansen, J., Rasmussen, J. B., and Acevedo, M. 2017. Inverse gene-for-gene interactions contribute additively to tan spot susceptibility in wheat. Theor. Appl. Genet. 130:1267-1276.

Liu, Z. H., Faris, J. D., Meinhardt, S. W., Ali, S., Rasmussen, J. B., and Friesen, T. L. 2004. Genetic and physical mapping of a gene conditioning sensitivity in wheat to a partially purified host-selective toxin produced by Stagonospora nodorum. Phytopathology 94:1056-1060.

Long, Y. M., Chao, W. S., Ma, G. J., Xu, S. S., and Qi, L. L. 2017. An innovative SNP genotyping method adapting to multiple platforms and throughputs. Theor. Appl. Genet. 130:597-607.

Lorieux, M. 2012. MapDisto: Fast and efficient computation of genetic linkage maps. Mol. Breed. 30:1231-1235.

Manning, V. A., and Ciuffetti, L. M. 2005. Localizatin of Ptr ToxA produced by Pyrenophora tritici-repentis reveals protein import into wheat mesophyll cells. Plant Cell 17:3203-3212.

Manning, V. A., Hamilton, S. M., Karplus, P. A., and Ciuffetti, L. M. 2008. The Arg-Gly-Asp-containing, solvent-exposed loop of Ptr ToxA is required for internalization. Mol. Plant-Microbe Interact. 21:315-325.

Manning, V. A., Pandelova, I., Dhillon, B., Wilhelm, L. J., Goodwin, S. B., Berlin, A. M., Figueroa, M., Freitag, M., Hane, J. K., Henrissat, B., Holman, W. H., Kodira, C. D., Martin, J., Oliver, R. P., Robbertse, B. Schackwitz, W., Schwartz, D. C., Spatafora, J. W., Turgeon, B. G. Yandava, C., Young, S., Zhou, S., Zeng, Q., Grigoriev, I. V., Ma, L.-J., and Ciuffetti, L. M. 2013. Comparative genomics of a plant-pathogenic 
fungus, Pyrenophora tritici-repentis, reveals transduplication and the impact of repeat elements on pathogenicity and population divergence. G3 (Bethesda) 3:41-63.

Martinez, J. P., Oesch, N. W., and Ciuffetti, L. M. 2004. Characterization of the multiple-copy host-selective toxin gene, ToxB, in pathogenic and nonpathogenic isolates of Pyrenophora tritici-repentis. Mol. PlantMicrobe Interact. 17:467-474.

Martinez, J. P., Ottum, S. A., Ali, S., Franci, L. J., and Ciuffetti, L. M. 2001. Characterization of the ToxB gene from Pyrenophora triticirepentis. Mol. Plant-Microbe Interact. 14:675-677.

McDonald, M. C., Ahren, D., Simpfendorfer, S., Milgate, A., and Solomon, P. S. 2018. The discovery of the virulence gene ToxA in the wheat and barley pathogen Bipolaris sorokiniana. Mol. Plant Pathol. 19:432-439.

McDonald, M. C., Oliver, R. P., Friesen, T. L., Brunner, P. C., and McDonald, B. A. 2013. Global diversity and distribution of three necrotrophic effectors in Phaeosphaeria nodorum and related species. New Phytol. 199:241-251.

McDonald, M. C., Taranto, A. P., Hill, E., Schwessinger, B., Liu, Z., Simpfendorfer, S., Milgate, A., and Solomon, P. S. 2019. Transposonmediated horizontal transfer of the host-specific virulence protein ToxA between three fungal wheat pathogens. MBio 10:e01515-e01519.

McKenna, A., Hanna, M., Banks, E., Sivachenko, A., Cibulskis, K., Kernytsky, A., Garimella, K., Altshuler, D., Gabriel, S., Daly, M., and DePristo, M. A. 2010. The Genome Analysis Toolkit: A MapReduce framework for analyzing next-generation DNA sequencing data. Genome Res. 20:1297-1303.

Meinhardt, S. W., Cheng, W., Kwon, C. Y., Donohue, C. M., and Rasmussen, J. B. 2002. Role of the arginyl-glycyl-aspartic motif in the action of Ptr ToxA produced by Pyrenophora tritici-repentis. Plant Physiol. 130:1545-1551.

Mergoum, M., Frohberg, R. C., Stack, R. W., Simsek, S., Adhikari, T. B., Rasmussen, J. B., Zhong, S., Acevedo, M., Alamri, M. S., Singh, P. K., Friesen, T. L., and Anderson, J. A. 2013. 'Prosper': A highyielding hard red spring wheat cultivar adapted to the North Central Plains of the USA. J. Plant Regist. 7:75-80.

Mironenko, N. V., Orina, A. S., and Kovalenko, N. M. 2020. Expression of ToxA and PtrPf2 genes of the Phytopathogen fungus Pyrenophora triticirepentis at the beginning of the infection process. Ecol. Genet. 18:149-155.

Moolhuijzen, P., See, P. T., Hane, J. K., Shi, G., Liu, Z., Oliver, R. P., and Moffat, C. S. 2018. Comparative genomics of the wheat fungal pathogen Pyrenophora tritici-repentis reveals chromosomal variations and genome plasticity. BMC Genomics 19:645.

Moolhuijzen, P., See, P. T., and Moffat, C. S. 2019. A new PacBio genome sequence of an Australian Pyrenophora tritici-repentis race 1 isolate. BMC Res. Notes 12:642.

Moolhuijzen, P., See, P. T., and Moffat, C. S. 2020a. PacBio genome sequencing reveals new insights into the genomic organisation of the multi-copy ToxB gene of the wheat fungal pathogen Pyrenophora triticirepentis. BMC Genomics 21:645.

Moolhuijzen, P. M., Muria-Gonzalez, M. J., Syme, R., Rawlinson, C., See, P. T., Moffat, C. S., and Ellwood, S. R. 2020b. Expansion and conservation of biosynthetic gene clusters in pathogenic Pyrenophora spp. Toxins (Basel) 12:242.

Moreno, M. V., Stenglein, S. A., Balatti, P. A., and Perello, A. E. 2008. Pathogenic and molecular variability among isolates of Pyrenophora tritici-repentis, causal agent of tan spot of wheat in Argentina. Eur. J. Plant Pathol. 122:239-252.

Nyarko, A., Singarapu, K. K., Figueroa, M., Manning, V. A., Pandelova, I., Wolpert, T. J., Ciuffetti, L. M., and Barbar, E. 2014. Solution NMR structures of Pyrenophora tritici-repentis ToxB and its inactive homolog reveal potential determinants of toxin activity. J. Biol. Chem. 289: 25946-25956.
Rees, R. G., Platz, G. J., and Mayer, R. J. 1982. Yield losses in wheat from yellow spot: Comparison of estimates derived from single tillers and plots. Aust. J. Agric. Res. 33:899-908.

Rybak, K., See, P. T., Phan, H. T., Syme, R. A., Moffat, C. S., Oliver, R. P., and Tan, K.-C. 2017. A functionally conserved $\mathrm{Zn}_{2} \mathrm{Cys}_{6}$ binuclear cluster transcription factor class regulates necrotrophic effector gene expression and host-specific virulence of two major Pleosporales fungal pathogens of wheat. Mol. Plant Pathol. 18:420-434.

Sarma, G. N., Manning, V. A., Ciuffetti, L. M., and Karplus, P. A. 2005. Structure of Ptr ToxA: An RGD-containing host-selective toxin from Pyrenophora tritici-repentis. Plant Cell 17:3190-3202.

Shabeer, A., and Bockus, W. W. 1988. Tan spot effects on yield and yield components relative to growth stage in winter wheat. Plant Dis. 72:599-602.

Shjerve, R. A., Faris, J. D., Brueggeman, R. S., Yan, C., Zhu, Y. Koladia, V., and Friesen, T. L. 2014. Evaluation of a Pyrenophora teres $\mathrm{f}$. teres mapping population reveals multiple independent interactions with a region of barley chromosome $6 \mathrm{H}$. Fungal Genet. Biol. 70:104-112.

Sperschneider, J., Dodds, P. N., Gardiner, D. M., Singh, K. B., and Taylor, J. M. 2018. Improved prediction of fungal effector proteins from secretomes with EffectorP 2.0. Mol. Plant Pathol. 19:2094-2110.

Strelkov, S. E., Kowatsch, R. F., Ballance, G. M., and Lamari, L. 2006. Characterization of the ToxB gene from North African and Canadian isolates of Pyrenophora tritici-repentis. Physiol. Mol. Plant Pathol. 67: 164-170.

Strelkov, S. E., and Lamari, L. 2003. Host-parasite interactions in tan spot (Pyrenophora tritici-repentis) of wheat. Can. J. Plant Pathol. 25: 339-349.

Sun, X. C., Bockus, W., and Bai, G. 2010. Quantitative trait loci for resistance to Pyrenophora tritici-repentis race 1 in a Chinese wheat. Phytopathology 100:468-473.

Talbot, N. J., Ebbole, D. J., and Hamer, J. E. 1993. Identification and characterization of MPG1, a gene involved in pathogenicity from the rice blast fungus Magnaporthe grisea. Plant Cell 5:1575-1590.

Untergasser, A., Cutcutache, I., Koressaar, T., Ye, J., Faircloth, B. C., Remm, M., and Rozen, S. G. 2012. Primer3-New capabilities and interfaces. Nucleic Acids Res. 40:ei15.

Wight, W. D., Labuda, R., and Walton, J. D. 2013. Conservation of the genes for HC-toxin biosynthesis in Alternaria jesenskae. BMC Microbiol. 13:165.

Wolpert, T. J., Dunkle, L. D., and Ciuffetti, L. M. 2002. Host-selective toxins and avirulence determinants: What's in a name? Annu. Rev. Phytopathol. 40:251-285.

Wyatt, N. A., Richards, J. K., Brueggeman, R. S., and Friesen, T. L. 2020. A comparative genomic analysis of the barley pathogen Pyrenophora teres $\mathrm{f}$. teres identifies subtelomeric regions as drivers of virulence. Mol. Plant-Microbe Interact. 33:173-188.

Yoshida, K., Saitoh, H., Fujisawa, S., Kanzaki, H., Matsumura, H., Yoshida, K., Tosa, Y., Chuma, I., Takano, Y., Win, J., Kamoun, S., and Terauchi, R. 2009. Association genetics reveals three novel avirulence genes from the rice blast fungal pathogen Magnaporthe oryzae. Plant Cell 21:1573-1591.

Zhong, S., Steffenson, B. J., Martinez, J. P., and Ciuffetti, L. M. 2002. A molecular genetic map and electrophoretic karyotype of the plant pathogenic fungus Cochliobolus sativus. Mol. Plant-Microbe Interact. 15: 481-492.

Zhong, Z., Marcel, T. C., Hartmann, F. E., Ma, X., Plissonneau, C., Zala, M., Ducasse, A., Confais, J., Compain, J., Lapalu, N., Amselem, J., McDonald, B. A., Croll, D., and Palma-Guerrero, J. 2017. A small secreted protein in Zymoseptoria tritici is responsible for avirulence on wheat cultivars carrying the Stb6 resistance gene. New Phytol. 214:619-631. 